\title{
Reading and Misreading 8-oxoguanine, a Paradigmatic Ambiguous Nucleobase
}

\author{
Anna V. Yudkina ${ }^{1,2, \dagger}$, Evgeniy S. Shilkin ${ }^{3, \dagger}$, Anton V. Endutkin ${ }^{1,4}$, Alena V. Makarova ${ }^{3, * \mathbb{C}}$ \\ and Dmitry O. Zharkov 1,2,* \\ 1 Novosibirsk State University, 1 Pirogova St., 630090 Novosibirsk, Russia; ayudkina@niboch.nsc.ru (A.V.Y.); \\ Aend@niboch.nsc.ru (A.V.E.) \\ 2 SB RAS Institute of Chemical Biology and Fundamental Medicine, 8 Lavrentieva Ave., \\ 630090 Novosibirsk, Russia \\ 3 RAS Institute of Molecular Genetics, 2 Kurchatova Sq., 123182 Moscow, Russia; \\ shilkinevgeniy.chem@gmail.com \\ 4 Podalirius Ltd., 77 Sacco and Vanzetti St, 630008 Novosibirsk, Russia \\ * Correspondence: amakarova-img@yandex.ru (A.V.M.); dzharkov@niboch.nsc.ru (D.O.Z.); \\ Tel.: +7-499-1960015 (A.V.M.); +7-383-3635187 (D.O.Z.) \\ + These authors contributed equally to this work.
}

Received: 26 April 2019; Accepted: 19 May 2019; Published: 23 May 2019

check for updates

\begin{abstract}
Dihydro-8-oxoguanine (oxoG) is the most abundant oxidative DNA lesion with dual coding properties. It forms both Watson-Crick (anti)oxoG:(anti)C and Hoogsteen (syn)oxoG:(anti)A base pairs without a significant distortion of a B-DNA helix. DNA polymerases bypass oxoG but the accuracy of nucleotide incorporation opposite the lesion varies depending on the polymerase-specific interactions with the templating oxoG and incoming nucleotides. High-fidelity replicative DNA polymerases read oxoG as a cognate base for $\mathrm{A}$ while treating oxoG:C as a mismatch. The mutagenic effects of oxoG in the cell are alleviated by specific systems for DNA repair and nucleotide pool sanitization, preventing mutagenesis from both direct DNA oxidation and oxodGMP incorporation. DNA translesion synthesis could provide an additional protective mechanism against oxoG mutagenesis in cells. Several human DNA polymerases of the X- and Y-families efficiently and accurately incorporate nucleotides opposite oxoG. In this review, we address the mutagenic potential of oxoG in cells and discuss the structural basis for oxoG bypass by different DNA polymerases and the mechanisms of the recognition of oxoG by DNA glycosylases and dNTP hydrolases.
\end{abstract}

Keywords: 7,8-Dihydro-8-oxoguanine; mutagenesis; DNA polymerases; base excision repair; DNA glycosylases; nucleotide hydrolases; translesion DNA synthesis

\section{Introduction}

Oxygen is an essential life element. At the same time, oxygen reacts with biomolecules and induces harmful effects on DNA. Produced both via endogenous (cellular metabolism) or exogenous (ionizing or UV radiation) reactions, reactive oxygen species (ROS) cause oxidative DNA damage.

Of all nucleobases, guanine has the lowest reduction potential and is the most vulnerable to ROS [1-5]. Among hundreds of oxidative stress-induced DNA lesions, 7,8-dihydro-8-oxo-2'deoxyguanine (oxoG) is one of the most abundant [6] (Figure 1). It can be generated by singlet oxygen $\left({ }^{1} \mathrm{O}_{2}\right.$, the electronically excited state of molecular oxygen which reacts preferentially with electron-rich G residues) [7] as well as by $\mathrm{HO}^{\bullet}$ and alkylperoxyl radicals [8]. Intermediates in reactions with purines induced by radicals (but not by singlet oxygen) can also be reduced, producing a series of formamidopyrimidine lesions $[8,9]$. OxoG can be formed both by direct oxidation of $G$ base in DNA 
and by oxidation of dGTP or GTP in the nucleotide pool. It is estimated that in vivo $1-2 \times 10^{3}$ oxoG lesions form daily in a single normal human cell, and this rate could allegedly rise to $10^{5}$ in cancer cells [10-14]. The steady state level of oxoG in repair-proficient mammalian cells is about $0.3-4.2$ per $10^{6}$ normal guanines $[15,16]$. Levels of oxoG are often used as a biomarker of oxidative damage and are considered a risk factor for degenerative diseases and cancer $[17,18]$.

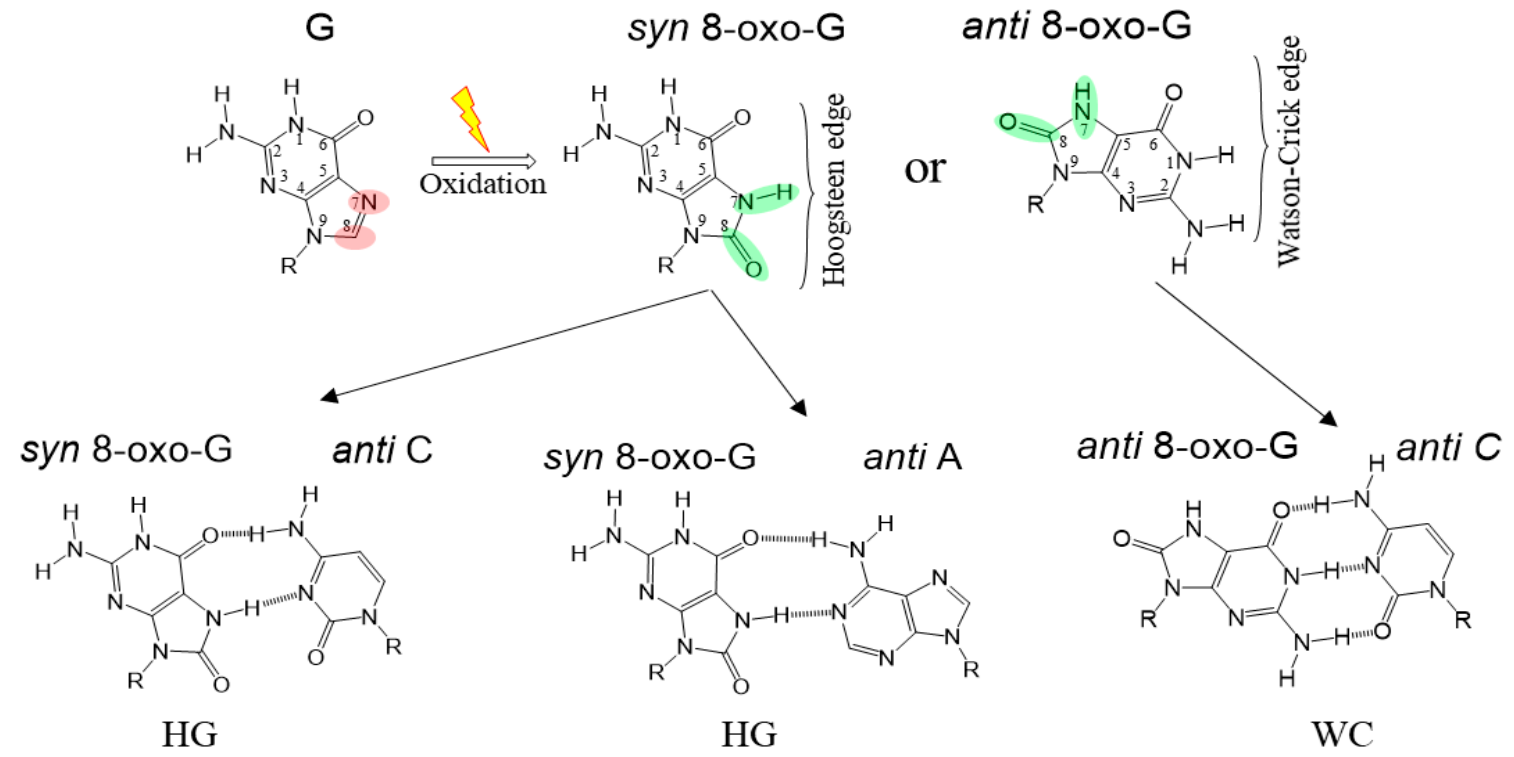

Figure 1. Structure of oxoG and formation of Watson-Crick (WC) and Hoogsteen (HG) base pairs with $\mathrm{A}$ and $\mathrm{C}$ nucleobases. Red and green circles represent the sites of modification before and after oxidation, respectively. Brackets indicate the edge of oxoG which is exposed for H-bonding in syn or anti conformation. Dashed lines show H-bonds.

OxoG attracted much attention as a lesion with a high mutagenic potential, which comes from its dual coding properties. Since the N7 atom of oxoG is a hydrogen bond donor, this damaged base readily forms stable oxoG(syn):A(anti) Hoogsteen mispair leading to $\mathrm{G}: \mathrm{C} \rightarrow \mathrm{T}$ :A transversions [19,20]. Moreover, oxoG itself is quite reactive toward ROS, its further oxidation yielding spiroiminodihydantoin and guanidinohydantoin, which direct misinsertion of $A$ and $G$ [21,22]. It was also shown that oxoG within DNA makes nearby DNA bases more prone to oxidation and represents a 'hot spot' of oxidative DNA damage $[23,24]$.

Aerobic organisms have developed multilevel defense systems to mitigate the harmful effects of oxidative DNA damage. Sanitization of the nucleotide pool through oxodGTP hydrolysis to the nucleoside monophosphate, base excision repair (BER) and DNA translesion synthesis (TLS) are the major cellular protective mechanisms against oxoG. The first two mechanisms are functionally integrated in a specific pathway, called the GO system, specifically preventing oxoG-induced mutagenesis. DNA glycosylases OGG1 and MUTYH and dNTPase MTH1 are three major tiers of the GO system in human cells, and their counterparts Fpg (MutM), MutY, and MutT play the same role in bacteria. TLS is not restricted to protection against oxoG but is more universal, allowing the cells to faithfully replicate their DNA in the presence of a variety of lesions. In this review, we address the mutagenic potential of oxoG and summarize and overview BER and TLS pathways of cellular defense against oxoG. We discuss the structural basis for oxoG bypass by human DNA polymerases as well as the mechanisms of oxoG recognition by DNA repair enzymes. 


\section{Miscoding Potential of oxoG}

\subsection{Misreading of oxoG by Replicative DNA Polymerases}

A central role in DNA replication belongs to replicative B-family DNA polymerases $\alpha, \delta$ and $\varepsilon$ [25]. Pol $\delta$ and Pol $\varepsilon$ operating on the lagging and leading DNA strands, respectively, are extraordinarily accurate. Average base substitution error rates of proofreading-proficient replicative DNA polymerases are typically $\geq 10^{-6}$ [26]. High-fidelity DNA polymerases incorporate nucleotides in strict accordance with the Watson-Crick (WC) base pairing rule. The geometry of their active site pockets assists proper alignment of an incoming nucleotide and enables the polymerase to accommodate only a correct base pair [27-29]. An intrinsic $3^{\prime} \rightarrow 5^{\prime}$ proofreading exonuclease activity of Pol $\delta$ and Pol $\varepsilon$ increases the accuracy of DNA replication by $2-3$ orders of magnitude $[26,28]$.

Many common DNA lesions (such as an abasic site, thymine glycol and $\mathrm{T}^{\wedge} \mathrm{T}$ cis-syn dimer) stall high-fidelity DNA polymerases [30-36]. In contrast, oxoG is not considered to be a blocking lesion, though the rate of DNA synthesis by high-fidelity DNA polymerases opposite oxoG is decreased and pausing of Pol $\delta$ in front of oxoG was observed [33,34,37-41]. High-fidelity polymerases bypass oxoG relatively efficiently in an error-prone manner. Pol $\alpha$, Pol $\delta$ and Pol $\varepsilon$ insert both dCMP and dAMP opposite oxoG (summarized in Table 1) [34,41-45]. High-fidelity DNA polymerases incorporate dAMP opposite oxoG more efficiently than dCMP in the absence of accessory proteins. Pol $\delta$ and Pol $\varepsilon$ are more accurate than $\operatorname{Pol} \alpha$. Importantly, high-fidelity DNA polymerases preferentially extend the A:oxoG mispair (Table 1) promoting the fixation of mutations [41-43]. Following the subsequent round of replication, this mispair leads to a G:C $\rightarrow \mathrm{T}$ :A transversion $[19,20]$.

Table 1. Activities of eukaryotic high-fidelity DNA polymerases opposite oxoG in vitro.

\begin{tabular}{|c|c|c|c|}
\hline Polymerase & Source & Efficiency of dNMPs Incorporation & $\begin{array}{l}\text { Efficiency of oxoG:C } \\
\text { and oxoG:A Extension }\end{array}$ \\
\hline \multirow[t]{2}{*}{ Pol $\alpha$} & human & $\begin{array}{c}\text { dAMP }>>\text { dCMP [39] } \\
\text { dAMP }>\text { dCMP [42] } \\
\text { dAMP }>\text { dCMP }(10: 1) \text { w/o RPA and (2:1) with RPA [44] }\end{array}$ & oxoG:A >> oxoG:C [42] \\
\hline & bovine & $\mathrm{dAMP}>\mathrm{dCMP}(7: 1)[42]$ & oxoG:A >> oxoG:C [42] \\
\hline \multirow[t]{2}{*}{ Pol $\delta$} & human & $\begin{array}{c}\text { dAMP }>\text { dCMP with PCNA [41] } \\
\text { dCMP > dAMP (6:4) with PCNA [45] } \\
\text { dAMP > dCMP (2:1) w/o PCNA and (3:1) with PCNA [44] }\end{array}$ & $\begin{array}{c}\text { oxoG:A > > oxoG:C with } \\
\text { PCNA [41] }\end{array}$ \\
\hline & bovine & $\begin{array}{c}\mathrm{dAMP}>\mathrm{dCMP}(2: 1) \text { w/o PCNA and dCMP }>\text { dAMP }(3: 1) \\
\text { with PCNA [43] } \\
\text { dAMP }>\text { dCMP }(5: 1) \text { with PCNA [42] }\end{array}$ & $\begin{array}{l}\text { oxoG:A >> oxoG:C with } \\
\text { PCNA and oxoG:A } \\
\text { oxoG:C w/o PCNA [43] }\end{array}$ \\
\hline Pol $\varepsilon$ & human & $\mathrm{dAMP} \sim \mathrm{dCMP}$ with PCNA [34] & \\
\hline
\end{tabular}

\subsection{OxoG-Induced Mutagenesis in Mammalian Cells}

Despite the ambiguous coding properties, the rate of oxoG-induced mutagenesis in cells is relatively low. Several studies monitored the fate of oxoG placed at a specific site on a chromosome [46] or a double- or single-stranded shuttle plasmid [20,47-50] in mammalian cells and demonstrated that oxoG is restored to $\mathrm{G}$ in $86-99 \%$ of cell clones. These studies reflect efficient base excision repair (BER) of oxoG in the cell. However, BER is not able to remove all oxoG lesions and DNA polymerases encounter oxoG during replication or repair-associated DNA synthesis. Importantly, aphidicolin, an inhibitor of $\operatorname{Pol} \alpha, \operatorname{Pol} \delta$, and $\operatorname{Pol} \varepsilon$, has a minor effect on the efficiency of oxoG bypass in cells suggesting that high-fidelity DNA polymerases are not essential for the DNA synthesis across oxoG [37]. TLS is an alternative mechanism of suppression of oxoG-induced mutagenesis in cells. This process relays on specialized DNA polymerases from X-and Y-families and is accurate in many cases. 
BER deficiency leads to increased mutagenesis and associated pathologies in humans and model animals. An excess of the $\mathrm{G}: \mathrm{C} \rightarrow \mathrm{T}: \mathrm{A}$ transversions was reported for germline mutations occurring in

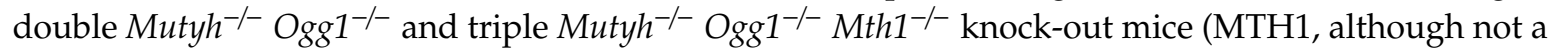
BER enzyme, cooperates with BER in the pathway that protects cells from oxoG, see Section 3.1). These mice are viable and fertile but have a shorter lifespan and develop tumors of various types in $35-66 \%$ of animals [51,52].

The G:C $\rightarrow$ T:A type of mutation signature (Signature 36) [53] is also characteristics of a hereditary MUTYH-associated polyposis (MAP) syndrome, which confers a marked risk of colorectal cancer in patients with germline biallelic MUTYH mutations [53]. This signature reflects persistent oxoG:A mismatches and is also found in other types of human cancer (neuroblastoma, pancreas, breast and gastric cancers) suggesting a link between oxidative DNA damage and cancer etiology in these organs [53]. The G:C $\rightarrow$ T:A mutation rate is sequence-dependent. The preferential oxidation of the $5^{\prime}-\mathrm{G}$ is observed in the GR context ( $R$, any purine), which is consistent with a reduced ionization potential of purine dinucleotides and a stacking-induced electron transfer [53-55]. Indeed, GAG $\rightarrow$ TAG and GAA $\rightarrow$ TAA nonsense mutations in APC and AMER1 tumor suppressor genes, as well as a characteristic GGT $\rightarrow$ TGT missense mutation (G12C) in KRAS proto-oncogene, were found in MAP syndrome patients [56]. The G:C $\rightarrow$ T:A type of mutation signature is the third most common somatic mutation in normal human aging [57], and promoter silencing in a set of genes with reduced expression in aging brain was attributed to accumulation of oxoG [58].

\subsection{The Structural Basis of Ambiguous Coding Potential of oxoG}

All high-fidelity DNA polymerases switch between an "open" binary complex with the primer-template, and a "closed" ternary complex with the incoming dNTP bound and the catalytic site, including two $\mathrm{Mg}^{2+}$ ions, fully assembled. Remarkably, recent study utilizing time-resolved X-ray crystallography revealed three divalent metal ions in the active site of Pol $\eta$ [59]; the third metal ion was observed also in Pol $\beta$ [60]. Fidelity of all DNA polymerases critically depends on the geometry of the formed base pair, which should fit the restraints of the base-binding pocket, fully formed only in the closed state [61-63].

Structural studies of DNA duplexes containing oxoG [64-67] and high-fidelity DNA polymerases (Pol I from Geobacillus stearothermophilus and T7 DNA polymerase) in complexes with oxoG containing DNA and incoming nucleotides [68-70] revealed the mechanism of mutagenic oxoG bypass. The glycosidic bond of the oxoG adopts two alternate syn or anti conformations (Figure 1). The anti conformation gives rise to the correct WC base pairing with an incoming (anti)dCTP [65,67-69]. However, in G. stearothermophilus Pol I structure, oxoG in anti conformation induces template distortion to avoid a potential steric clash between the bulky $\mathrm{O}^{8}$ atom and the $\mathrm{O}^{\prime}$ atom of the 2-deoxyribose (Figure 2A). This template distortion results in the polymerase active site distortions that resemble those induced by mismatches in undamaged DNA [69]. Therefore, the (anti)oxoG:(anti)C WC base pair is recognized as a mismatch, which lead to low efficiency of dCMP incorporation and poor extension from the (anti)oxoG:(anti)C base pair.

In the syn conformation, oxoG functionally mimics thymine (T). Oxidation of $\mathrm{G}$ (at the $\mathrm{C} 8$ atom) induces the N7 atom protonation converting of the N7 from H-bond acceptor to H-bond donor which results in similarity of the oxoG HG edge with the T WC edge (Figure 1) $[64,66]$. The syn conformation of the lesion exposes the HG edge for H-bonding with the incoming dATP nucleotide in the anti conformation generating a pair similar to (anti)T:(anti)A structurally. Since the pro-mutagenic (syn)oxoG:(anti)A mispair mimics the geometry of a correct base pair, it does not cause significant DNA helix and polymerase active site distortions and escapes proofreading (as seen in the G. stearothermophilus Pol I structure) [69].

At the same time, attempts to crystallize wild-type T7 DNA polymerase in the process of inserting dATP opposite oxoG resulted in the crystallization of a catalytically inactive open conformation of the polymerase lacking bound dATP [68]. The addition of high ddCTP concentration was required in 
order to obtain high-quality crystals of the oxoG:ddCTP complex [68]. It was suggested that (1) oxoG binds less tightly to the T7 polymerase active site with than an undamaged base and/or base-pairing interactions between oxoG and the incoming nucleotide are less stable; (2) oxoG destabilizes the closed, active conformation of the polymerase [68]. The latter explanation is supported by the observation that the K536A mutant of T7 DNA polymerase allows oxoG to rotate to syn and close the fingers domain, increasing the error rate $\sim 40$-fold [70].

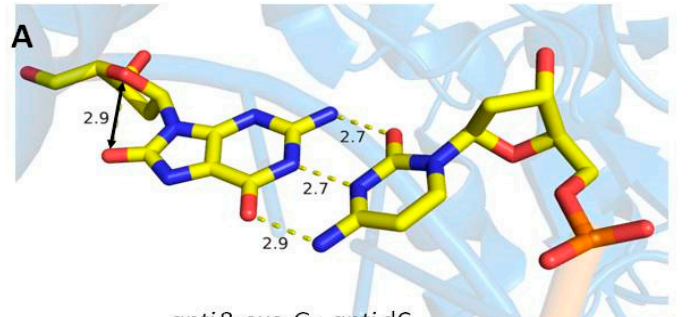

anti 8-oxo-G : anti dC

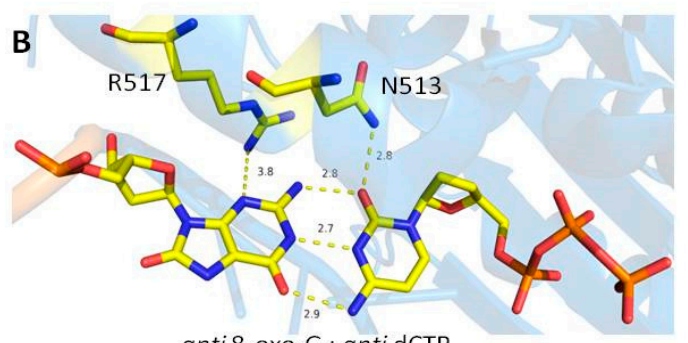

anti 8-oxo-G : anti dCTP

C

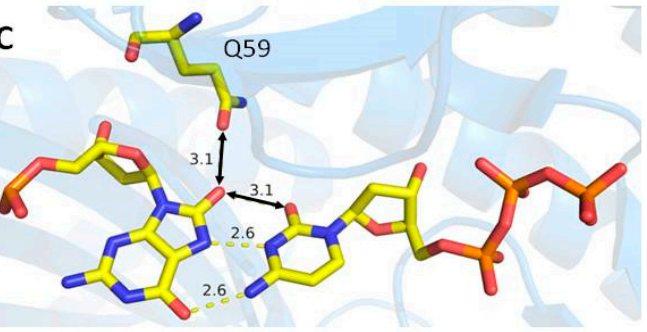

syn 8-oxo-G : anti dCTP

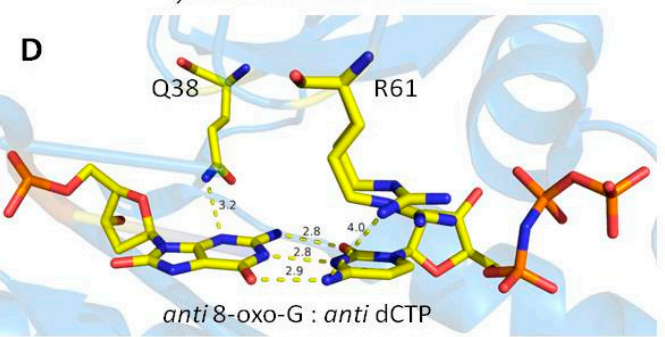

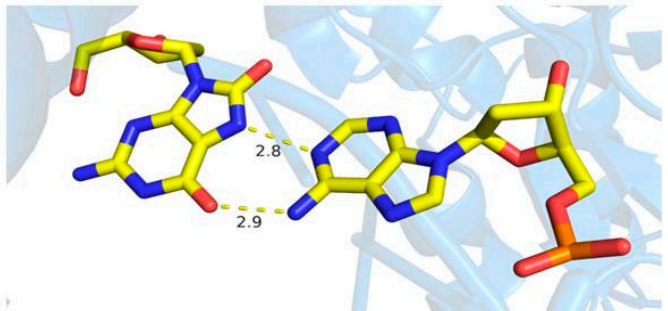

syn 8-oxo-G : anti dA

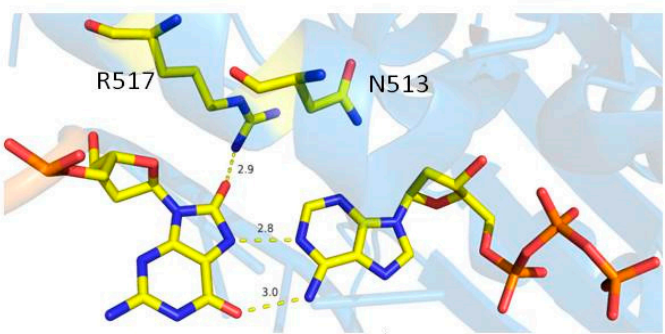

syn 8-oxo-G : anti dATP

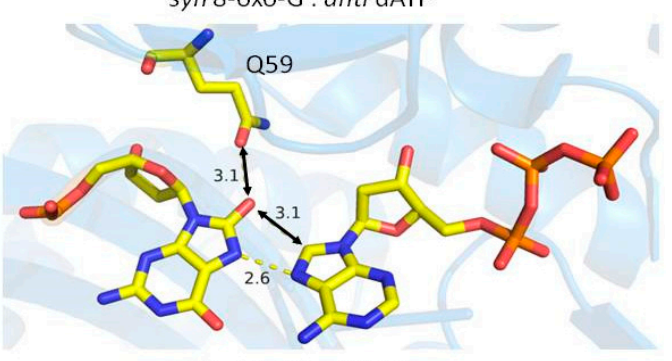

syn 8-oxo-G : syn dATP

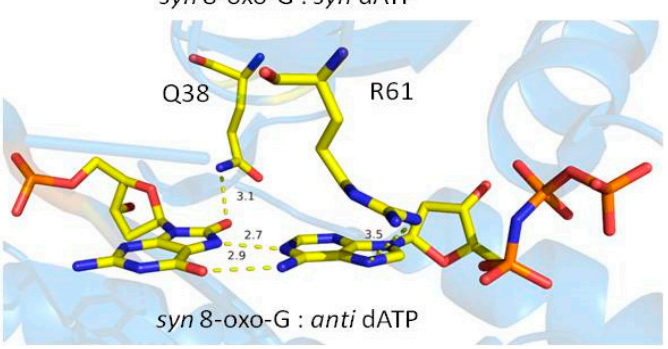

Figure 2. Interactions between the templating oxoG and incoming nucleotides in the active sites of different DNA polymerases. (A) Post-insertion complexes of G. stearothermophilus Pol I with the templating oxoG paired with dC (1U47) or dA (1U49) [69], (B) pre-insertion complexes of human Pol $\lambda$ with the templating oxoG paired with dCTP (5III) and dATP (5IIJ) [71], (C) pre-insertion complexes of human Pol ı with the templating oxoG paired with dCTP (3Q8P) and dATP (3Q8Q) [72], (D) pre-insertion complexes of human Pol $\eta$ with the templating oxoG paired with dCTP (4O3P) and dATP (4O3O) [73]. The database accession numbers are shown near each pair. The conformation of each nucleotide and the type of interactions are indicated: WC, Watson-Crick; HG, Hoogsteen. Atoms are colored as following: $\mathrm{C}$ (yellow), N (blue), O (red), P (orange). Yellow dashed lines indicate H-bonds between nucleobases or interaction with the enzyme amino acid. Double arrowed solid lines represent repulsive interactions. The distances $(\AA)$ are indicated. 
Interestingly, while X-ray and NMR structures show that DNA with oxoG lesion appears virtually identical to the corresponding unmodified duplex and the oxoG:C has a normal high-affinity Watson-Crick base pairing arrangement, thermodynamic studies indicate that oxoG has a local destabilizing effect on DNA (destabilizes oxoG:C and 5' flanking base pairs) [74,75]. The origin of this destabilization was attributed to the loss of a cation-binding site in the major groove (due to the replacement of an electronegative $\mathrm{N} 7$ with an electropositive $\mathrm{N}-\mathrm{H}$ ), reduction in the level of hydration and reduced base stacking [74] and to steric repulsion effects that propagate from $\mathrm{O}^{8}$ via the sugar pucker to the $3^{\prime}$-phosphate $[75,76]$. It is possible that differences in local DNA stability and its conformational dynamics could affect DNA synthesis efficiency across oxoG.

\section{Recognition of oxoG by Genome Defense Systems}

\subsection{GO System: An Overview}

Shortly after the discovery of oxoG and its mutagenicity, it was shown that $E$. coli cells possess three enzymes, Fpg (MutM), MutY, and MutT, that together prevent accumulation of oxoG in DNA [77-79]. Collectively, these enzymes are termed the "GO system". Fpg removes oxoG from oxoG:C pairs, which are generated either by $G$ oxidation in DNA or by incorporation of oxodGMP opposite to $C$ by DNA polymerases [80-82]. If not repaired before replication, oxoG can direct dAMP misincorporation, and the removal of oxoG from the resulting oxoG:A mispair would immediately fix the $G: C \rightarrow A: T$ mutation (Figure $3 \mathrm{~A}$ ). To prevent such post-replicative mutagenesis, Fpg has a negligible activity on oxoG:A substrates, and these mispairs are instead processed by MutY, which excises the normal A base $[83,84]$. The repair DNA synthesis can then incorporate either dCMP or dAMP opposite oxoG; in the former case, the repair can be correctly conducted by Fpg, whereas in the latter case, the MutY/polymerase cycle can be repeated $[77,78]$. Like oxoG in DNA, oxodGTP also has ambiguous coding properties; it can be efficiently incorporated opposite A, and the MutY-initiated repair would lead to an A:T $\rightarrow$ C:G mutation $[79,85]$ (Figure 3B). To prevent this, MutT hydrolyses oxodGTP and oxoGTP to monophosphates $[86,87]$.

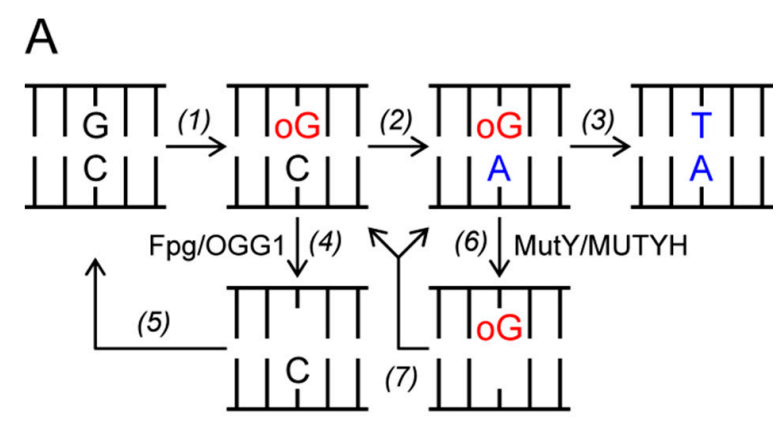

B

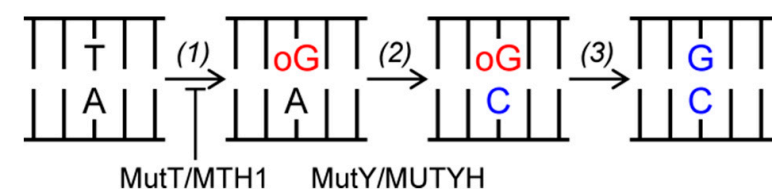

Figure 3. OxoG-induced mutagenesis and the GO system. (A) oxoG can appear in DNA through oxidation of $G$ (1) and direct misinsertion of A during replication (2); if not repaired, oxoG:A mispair produces T:A after the second round of replication. OxoG can be removed by Fpg/OGG1 from oxoG:C before the replication (4) and the subsequent BER steps restore the G:C pair (5). Alternatively, after the replication, A can be removed from oxoG:A (6) allowing the repair DNA polymerases to insert either C or A opposite to oxoG (7). (B) oxoG can also appear in DNA through incorporation from oxodGTP. If this occurs opposite to A (1), the repair by MutY/MUTYH (2) is mutagenic, causing a T:A-to-G:C transversion (3). MutT/MTH1 hydrolyzes oxodGTP and intercepts this pathway at the beginning. 
Higher eukaryotes, including humans, have a fully operational GO system. MUTYH and MTH1 (NUDT1) proteins are sequence homologs and functional analogs of MutY and MutT, respectively [88-91]. OGG1 is a functional analog of Fpg, although these two enzymes lack sequence homology and are not structurally similar [92-94]. However, some eukaryotes such as baker's yeast and Drosophila lack MutY homologs and have to rely on the mismatch repair system instead to recognize oxoG:A mispairs [95].

\subsection{DNA Glycosylases Recognizing and Excising oxoG}

\subsubsection{Fpg}

E. coli Fpg protein has been extensively characterized as a DNA glycosylase that excises oxoG and many other oxidatively damaged or otherwise modified purine and even pyrimidine lesions from DNA [80-82,96]. However, this wide specificity is mostly observed on duplex oligonucleotide substrates, and Fpg specificity in high-molecular-weight DNA is limited to oxoG, 2,6-diamino-4-hydroxy-5-formamidopyrimidine (FapyG) and its $N^{5}$-methylated derivative, and 4,6-diamino-5-formamidopyrimidine (FapyA) [82,97]. Since Fapy and 8-oxo purine products originate from the common primary oxidation intermediate [9], and since the mutagenic spectra of $f p g$ strains are consistent with oxoG miscoding properties [79,98], oxoG and possibly Fapy bases seem to be natural Fpg substrates, and the other reported specificities are likely spurious.

The structures of Fpg from E. coli [99], Thermus thermophilus [100], Lactococcus lactis [101], and G. stearothermophilus [102] defined a novel structural superfamily characterized by the presence of two conserved DNA-binding motifs, the helix-two-turn-helix (H2TH) motif and a single Cys 4 -hairpin zinc finger (some eukaryotic homologs possess a "zincless finger", a structurally identical hairpin lacking the zinc binding site). As most other DNA glycosylases, Fpg flips the damaged nucleotide out of the helix and binds it in a dedicated lesion-recognition pocket. Unfortunately, this pocket is disordered in many Fpg-DNA crystals that lack the damaged base, so only a few structures are available to analyze the determinants of oxoG specificity, and even these are discordant. Several G. stearothermophilus Fpg structures were solved using a catalytically inactive E2Q mutant [103-105], showing oxoG in the syn orientation, with a ${ }^{220}$ TVRTY $^{224}$ loop encircling $\mathrm{O}^{6}$ of oxoG and forming a "crown" of four main chain amines, any two of which can donate hydrogen bonds to $\mathrm{O}^{6}$. The Watson-Crick edge of oxoG is additionally locked in place by $\mathrm{O} \gamma[\mathrm{Thr} 223] \ldots \mathrm{N} 1$ [oxoG], $\mathrm{N}^{2}$ [oxoG] ... O $\gamma$ [Thr223], and $\mathrm{N}^{2}$ [oxoG] ... Oع2[Glu77] hydrogen bonds. The damaged base selectivity is provided by the oxoG pyrrolic N7 donating a hydrogen bond to Ser219 main-chain carbonyl, whereas $\mathrm{O}^{8}$ does not appreciably contribute to interactions distinguishing $\mathrm{G}$ from oxoG (Figure 4A). Surprisingly, in the crystals of wild-type L. lactis Fpg bound to DNA containing $1^{\prime}-4^{\prime}$-carba-FapyG or $N^{5}$-benzyl-1'-4'-carba-FapyG, which are uncleavable due to a methylene group substituting for $\mathrm{O}^{\prime}$, the damaged base is rotated almost $180^{\circ}$, residing in the anti-orientation [106,107] (Figure 4B). Even more surprisingly, the crown around $\mathrm{O}^{6}$ is formed by the homologous loop both in the syn and the anti-orientation $[106,108]$. Yet another orientation, in the middle of the syn range and almost orthogonal to those discussed above, is observed in L. lactis Fpg bound to DNA containing $1^{\prime}-4^{\prime}$-carba-oxoG [109]. Here, the distinguishing interaction seems to be the $\mathrm{N}[\mathrm{Pro1}] \ldots \mathrm{O}^{8}[\mathrm{oxoG}]$ hydrogen bond, and $\mathrm{O}^{6}$ is not fixed. 

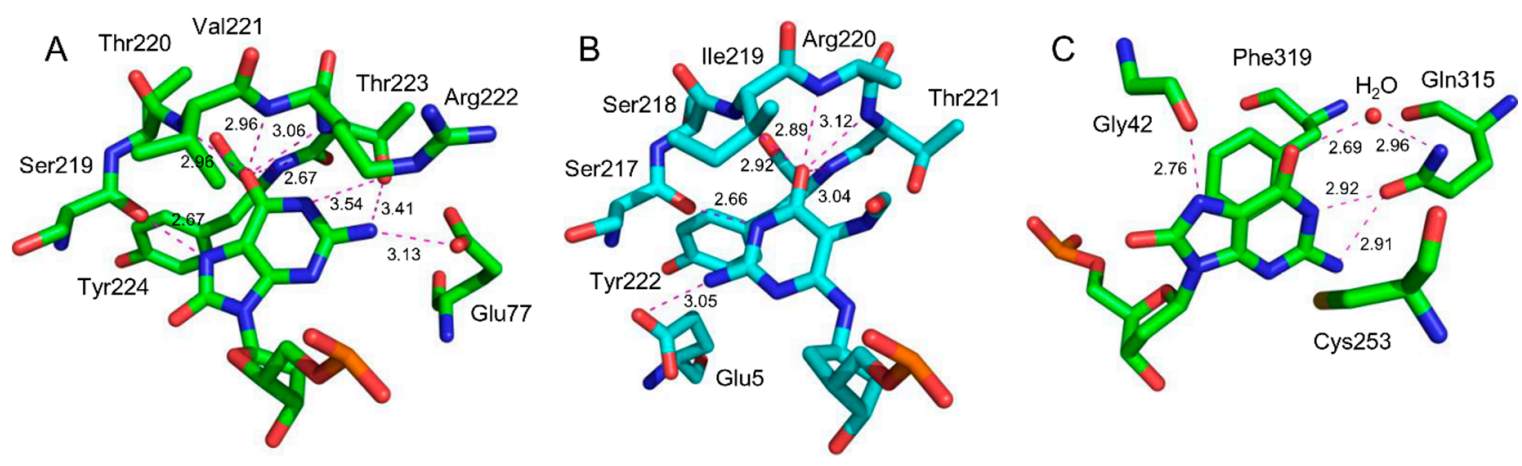

Figure 4. Recognition of oxidative lesions by 8-oxoguanine-DNA glycosylases. (A) G. stearothermophilus Fpg recognizing oxoG in the syn orientation (1R2Y) [103]. (B) L. lactis Fpg recognizing FapyG in the anti-orientation (1XC8) [106]. (C) human OGG1 recognizing oxoG in the anti-orientation (1EBM) [110]. Only the damaged nucleotide and the residues in its immediate vicinity are shown. Numbers indicate the distances between putative hydrogen bond donors and acceptors; note that only two of the possible four hydrogen bonds with $\mathrm{O}^{6}(\mathrm{~A}, \mathrm{~B})$ can exist at any given moment.

The discrepancies between the crystal structures prompted several molecular dynamics investigations of the Fpg pre-catalytic complex [108,111-114]. Based on their results, the high syn orientation of oxoG in G. stearothermophilus Fpg structures seems to be an artifact due to the E2Q mutation that disrupts an oxyanion hole and disturbs the $\mathrm{H} 2 \mathrm{TH}$ motif. The high anti orientation seems to be more relevant.

The structures and models of Fpg proteins from different species also reveal the basis of the strong "C-versus-A opposite-base" discrimination. An absolutely conserved Arg residue is inserted into the space vacated by the everted oxoG and donates two hydrogen bonds to $\mathrm{O}^{2}$ and $\mathrm{N} 3$ of the orphaned C [99,101,102]. While G or T are structurally tolerated as the bases opposite to oxoG [102], and oxoG is removed from such mispairs quite efficiently $[81,115]$. A opposite to oxoG is unstable and tends to be expelled from the helix, destabilizing the whole complex [108].

\subsubsection{OGG1}

Eukaryotic oxoG glycosylase OGG1 shares neither sequence homology nor structural similarity with Fpg, yet the structural specificities of both enzymes coincide almost perfectly [116]. OGG1 belongs to the helix-hairpin-helix $(\mathrm{HhH})$ superfamily, defined by the presence of the HhH motif and a "loop" (rather, an extended stretch) rich in Gly, Pro and Val and carrying a catalytic Asp residue [117,118]. The second catalytic residue is Lys (Lys249 in human OGG1) located at the beginning of the second helix in the $\mathrm{HhH}$ motif, whose $\varepsilon$-amino group is the nucleophile in the reaction [119].

The structure of human OGG1 K249Q catalytic mutant bound to oxoG:C-containing DNA have been solved $[110,120]$ and clearly reveals that the main structural determinant of oxoG recognized by the enzyme in the pre-catalytic complex is the pyrrolic N7 rather than the exocyclic $\mathrm{O}^{8}$. The main-chain carbonyl of Gly42 accepts a hydrogen bond from N7, while $\mathrm{O}^{8}$ points into a hydrophobic pocket essentially devoid of hydrogen bond-forming capabilities (Figure 4C). The oxoG base remains in the anti-orientation and is sandwiched between the side chains of aromatic Phe319 and Cys253, which, as suggested by QM/MM calculations, likely exists as a thiolate anion [120]. The Watson-Crick edge is recognized by Gln315 through two direct hydrogen bonds and a water bridge. Replacement of Cys253 or Gln315 with bulkier side chains strongly interferes with oxoG excision but affects the abasic site site cleavage to a much lower degree $[121,122]$. Given that the electric dipoles of $G$ and oxoG are almost opposite, and that 7-deazaguanine and 7-deaza-8-azaguanine cannot form bonds to Gly 42 but still efficiently enter the active site [120], it seems that stabilization of oxoG in the active site pocket is not limited to hydrogen bonding but to a significant degree relies on hydrophobic and electrostatic interactions with the enzyme. Interestingly, the excised oxoG is retained in the pocket, keeping the same pattern of interactions, and may participate in the following reaction steps as a general base [123]. 
Besides human OGG1, structures of two bacterial enzymes from the same family are known. OGG1 from Clostridium acetobutylicum is solved in the apo form, as well as with oxoG deoxynucleotide and oxoG:C-containing DNA bound [124,125], and recognizes oxoG in exactly the same way as human protein does. OGG1 from another species, Thermoanaerobacter tengcongensis, has been solved only with abasic site-containing DNA [126], but since all oxoG-recognizing residues are conserved in this protein, the mode of lesion recognition is expected to be identical.

\subsubsection{Dynamic oxoG Recognition}

An extended series of structures of Fpg [102-105,127-131] and OGG1 [110,120,121,123,132-138], together with molecular dynamic simulation of conformational transition between these intermediates [139-142], and stopped-flow studies [115,122,140,143-150] produced a multistep oxoG recognition model that turned out to be surprisingly similar for these two enzymes despite their structural dissimilarity. Both Fpg and OGG1 kink DNA by $40^{\circ}-50^{\circ}$ and insert an aromatic wedge (Phe or Tyr) into the base stack, causing the sampled base pair to buckle. This distortion is tolerated by G:C pairs without breaking the complementary bonding but less stable oxoG:C pairs open, and oxoG flips out of the duplex. Extrusion through both the minor and major grooves has been considered, with the major-groove path appearing energetically more favorable $[120,139,141]$. Along the eversion trajectory, oxoG, through its distinguishing N7-C8 edge, forms specific transient intermediates both with protein residues and with DNA phosphates near the lesion. These stabilized conformers favor oxoG eversion and essentially prohibit extrahelical states for $G$. Even if $G$ is flipped out, its most stable extrahelical conformer puts it into a so-called "exo site", an alternative base-binding site in the enzyme molecule, where the $\mathrm{C}^{\prime}{ }^{\prime}$ atom is inaccessible for the reaction chemistry. Thus, both Fpg and OGG1 selectively destabilize the intrahelical position of oxoG and stabilize its extrahelical conformers while destabilizing extrahelical G. Combined, this produces $>10^{6}$-fold selectivity in favor of oxoG.

An intriguing possibility of indirect remote oxoG detection by MutY was suggested based on the sensitivity of its $\left[\mathrm{Fe}_{4} \mathrm{~S}_{4}\right]^{2+}$ (FeS) cluster to the electron-deficient DNA stretches [151-155]. MutY with the oxidized FeS cluster binds DNA much more tightly than the non-oxidized form, and it has been proposed that, upon DNA binding, MutY can eject an electron into the base stack, where it could be intercepted by an oxidized base or by another bound MutY molecule. This would rapidly concentrate MutY molecules at oxidized regions of DNA, ready to engage in the repair. The biological relevance of this model remains to be elucidated.

\subsection{NUDIX Domain: A Deceitful Similarity}

\subsubsection{MutT and MTH1 (NUDT1)}

As an antimutator, the MutT gene may be the most important member of the GO system, since its inactivation produces the largest increase in the mutation rate, far exceeding the effect of Fpg or MutY deficiencies [79]. Cloning of E. coli MutT pyrophosphohydrolase and many homologous sequences defined a large superfamily of enzymes hydrolyzing NUcleoside DIphosphates linked to other (X) moieties (NUDIX) and, in addition to the nucleotide pool sanitization, operating in many metabolic and signaling pathways $[156,157]$. All NUDIX enzymes possess a highly conserved motif, GX5EX7RE(I/L/V)XEEXG(I/L/V), encompassing the divalent cation $\left(\mathrm{Mg}^{2+}\right.$ or $\left.\mathrm{Mn}^{2+}\right)$ binding site and the catalytic site. The human homolog, MTH1 (or NUDT1), belongs to the same superfamily but forms a cluster separate from bacterial MutT.

The structure of E. coli MutT was determined both by X-ray crystallography and by NMR, but there is a large discrepancy between these data regarding the binding site for oxoG in the structure of MutT. According to the crystal structure of E. coli MutT bound to oxodGMP [158], the damaged nucleotide is bound in the syn conformation in a deep pocket inside the protein, with oxoG specifically recognized by the Asn119 side chain forming bonds to N7 and $\mathrm{O}^{6}$ (Figure 5A). The Watson-Crick edge of oxoG is locked in place by the main chain amide and carbonyl of Phe35 engaging $\mathrm{O}^{6}, \mathrm{~N} 1$, 
and $\mathrm{N}^{2}$. The catalytic divalent cation $\left(\mathrm{Mn}^{2+}\right.$ in the structure) is coordinated by the Gly37 main-chain carbonyl, Glu56 side-chain carboxyl, and the $\alpha$ phosphate. In the structure of a MutT homolog from Rhodospirillum rubrum in a complex with ADP (PDB ID 3R03, unpublished), the syn nucleoside is bound in the same pocket but is not inserted as deeply as oxodGMP in E. coli structures. In contrast, four sets of conformers of MutT/oxodGMP identified by NMR [159] map the oxidized nucleotide loosely bound at different places at the surface, with scarce interactions with the enzyme; a similar situation is observed with $\alpha, \beta$-methylene-ATP as a ligand [160]. The much better nucleotide coordination and the similarity with the structure of the human enzyme (see below) indicate that the crystal structure but not the NMR structures faithfully describes the MutT/substrate complex. Molecular dynamics studies [161] suggest that the high specificity of MutT for the damaged dNTP $\left(k_{\mathrm{sp} \mathrm{oxoG}} / k_{\mathrm{sp} \mathrm{G}} \sim 6000\right.$ [162] $)$ is partially due to a change in the enzyme conformation upon substrate binding that is more favorable for oxodGTP than for dGTP.
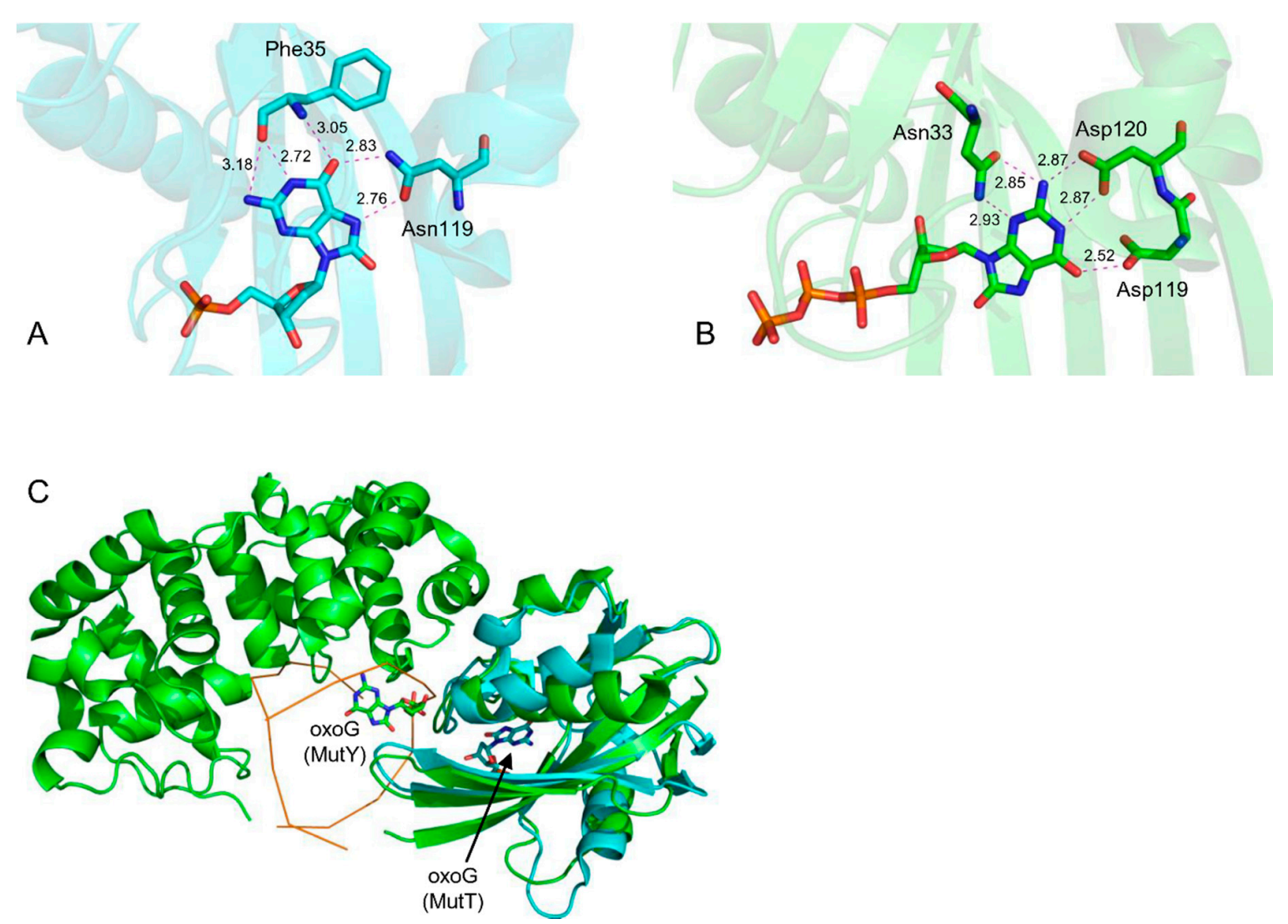

Figure 5. Recognition of oxoG by NUDIX domain enzymes. (A) E. coli MutT recognizing oxodGMP in the syn conformation (3A6T) [158]. (B) human MTH1 recognizing oxodGTP in the anti conformation (5GHI) [163]. Numbers indicate the distances between putative hydrogen bond donors and acceptors; in (B), $\mathrm{O}^{6}$ of oxoG is suggested to be protonated, and either $\mathrm{O}^{6}$ or $\mathrm{N} 1$ can form a hydrogen bond at any given moment. (C) overlay of G. stearothermophilus MutY bound to DNA containing an A:oxoG pair (green; 1RRQ) [164] and E. coli MutT (cyan; 3A6T) illustrating conservation of the MutT's oxoG-binding pocket in the structure of MutY. The DNA backbone is schematically shown as a brown line.

Unexpectedly for a seemingly important substrate-recognizing residue, Asn119 is not conserved in the MutT family (changed to Asp in many sequences) and the MTH1 family uniformly contains Asp in this position. Also, Phe35 is conserved in MutT but replaced with Gly in MTH1 sequences. The structures of MTH1 from several vertebrate species, including humans, bound to a variety of modified nucleotides, revealed a binding site quite similar to MutT but a surprisingly different mode of oxoG recognition $[163,165-168]$. In the active site pocket, the sugar of oxodGTP is flipped $\sim 180^{\circ}$ 
relative to the MutT structure, and the damaged base is anti, coplanar with oxoG base in MutT but orthogonal to it in this plane. The key amino acid residues appear to be Asp119 and Asp120 (the latter is homologous to Asn119 of E. coli MutT), which coordinate $\mathrm{O}^{6}, \mathrm{~N} 1$, and $\mathrm{N}^{2}$, and Asn33 forming bonds to $\mathrm{N}^{2}$ and $\mathrm{N} 3$ of oxoG (Figure 5B). Such an arrangement requires one of the Asp residues to be protonated and/or the oxoG base to switch from the 6-keto to the 6-enol tautomer. No oxoG-specific interactions are obvious; a water molecule is observed at the Hoogsteen edge coordinated by $\mathrm{N} 7$ and $\mathrm{O}^{6}$ but equally capable of bond formation with either $\mathrm{G}$ or oxoG. In fact, the oxoG-vs-G specificity of MTH1 is much lower compared to MutT, with $k_{\mathrm{sp} \mathrm{oxoG}} / k_{\mathrm{sp} \mathrm{G}} \sim 14$ [169]. On the other hand, the Asp-Asp mechanism with variable protonation states could account for the wide substrate specificity of MTH1, which, in addition to oxodGTP/oxoGTP, efficiently hydrolyzes ribo- and deoxyribonucleoside triphosphates of 8-oxoadenine, 2-oxoadenine, $\mathrm{O}^{6}$-methylguanine, and 8-chloroguanine [168-171]. It seems that MTH1 would be more accurately described as a general purine dNTP pool sanitization enzyme, rather than an oxoG-specific one.

\subsubsection{MutY and MUTYH}

MutY was discovered as an adenine glycosylase specific for A:G and A:C mispairs [172-175] and was later found to prefer A:oxoG substrates $[77,84,176]$. Limited proteolysis revealed that MutY can be easily separated in two domains, a large $\mathrm{N}$-terminal catalytic domain that recognizes A opposite $\mathrm{G}$ and oxoG equally well and a small C-terminal one that increases the specificity for oxoG by about tenfold $[176,177]$. After the C-terminal domain was discovered to possess limited sequence homology to MutT and share the same fold as MutT $[178,179]$ it was suggested that the mechanisms of oxoG recognition by MutT and MutY are also the same. However, when the structure of full-length MutY from $G$. stearothermophilus became available $[164,180]$ it was immediately clear that the position of the oxoG base relative to the C-terminal domain is very different from that in MutT/MTH1 (Figure 5C). In MutY, oxoG is stacked to the Tyr wedge (Tyr88 in G. stearothermophilus MutY, Tyr82 in the E. coli enzyme), and donates a hydrogen bond from its N7 to O $\gamma$ [Ser308], which in turn is hydrogen-bonded to O[Phe307]. If $G$ is present instead of oxoG, Ser308 could donate a hydrogen bond to N7 but the $\mathrm{O} \gamma\left[\right.$ Ser308] ... O [Phe307] would be lost, making $\mathrm{G}$ a less favorable base at this position. $\mathrm{O}^{8}$ of oxoG is pressed against the $\pi$-system of Phe307.

Intriguingly, a superposition of MutT and MutY NUDIX domains reveals that the deep pocket for oxoG binding is still present in MutY, albeit lined with different amino acid side chains. The pocket is conveniently located to bind oxoG flipped out of DNA (Figure 5C). Although such conformation is not observed in the static structure, in a stopped-flow study with full-length E. coli MutY and a fluorescent base reporter [181] it was suggested that both the target A and the opposite oxoG could flip out. MutY can be cross-linked to DNA through oxidized oxoG or photocrosslinked through BrG [181,182], raising the possibility that at least transient eversion of oxoG takes place during its recognition by the NUDIX domain of MutY.

\subsubsection{Other NUDIX Domain Enzymes}

In addition to MutT/MTH1, oxoG-containing nucleotides were reported to be substrates for human ADP-ribose diphosphatase NUDT5 [183,184], mycobacterial diadenosine hexaphosphate hydrolase MutT1 [185,186], Caenorhabditis elegans asymmetrical bis(5'-nucleosyl)-tetraphosphatase NDX-4 [187], Bacillus subtilis apyrase YtkD [188], Drosophila diphosphoinositol-polyphosphate diphosphatase Aps [189], yeast coenzyme A pyrophosphatase Pcd1p [190] and mammalian dNTP hydrolases MTH2 (NUDT15) [191,192] and MTH3 (NUDT18) [193], all belonging to the NUDIX superfamily. Some of these enzymes also hydrolyze oxodGDP and oxoG-containing ribonucleotides. The biological significance of these reactions is unclear, since other substrates for them are also described, often processed more efficiently than oxoG nucleotides. The crystal structures with oxoG nucleotides have been reported for NUDT5 [184] and MutT1 [194]. NUDT5 is a dimeric protein, in which oxodGDP and oxodGMP adopt a totally different conformation compared with MutT/MTH1, lying at the dimer 
interface in a cleft between the NUDIX domain and the N-terminal $\beta$-sheet domain of one subunit and the N-terminal domain of the other subunit. The base is sandwiched between two Trp side chains belonging to different subunits, and no oxoG-specific bonds are formed [184]. MutT1 displays oxoG nucleotide binding at three different sites in the crystal, one corresponding to the MutT/MTH1 binding pocket, and two others at the interface between two molecules in the crystallographic unit (likely not physiological). In the binding pocket, oxodGTP is oriented differently from either MutT or MTH1 conformation; the base is squeezed between two Tyr side chains, and both $\mathrm{N} 7$ and $\mathrm{O}^{8}$ are recognized by well-coordinated water molecules [194]. This configuration is probably more specific for oxoG than a single water molecule found at the Hoogsteen edge of MTH1, although MutT1 degrades oxodGTP and dGTP equally well [185].

Overall, the available structures unambiguously show that NUDIX domains, despite their very high structural similarity and reasonable sequence homology in various proteins, can engage in very different modes of oxoG binding, and should not be regarded as specific oxoG-recognizing modules.

\section{Translesion Synthesis Past oxoG}

To prevent oxoG-induced mutagenesis, the replication machinery switches from high-fidelity B-family DNA polymerases to specialized X-family and Y-family DNA polymerases, which efficiently and often accurately bypass oxoG. X-family enzymes also function in eukaryotic BER, and, in particular, are important for the insertion opposite oxoG in the GO system.

\subsection{X-family DNA Polymerases}

\subsubsection{DNA Polymerase $\beta$}

DNA polymerase $\beta$ is the main BER polymerase in mammals [195,196]. Studies suggest that Pol $\beta$ has a slight preference to incorporate dCMP opposite oxoG [42,197-199] (Table 2). This fidelity, however, is still higher than in replicative DNA polymerases (Table 1). Also, Pol $\beta$ extends primers with the 3 '-terminal $C$ paired with oxoG $\sim 15$-fold more efficiently than those with $3^{\prime}$-terminal A [200].

Pol $\beta$ complexes with template oxoG and incoming dNTPs are extensively characterized by X-ray crystallography $[199,200,213-216]$ and by molecular dynamics $[217,218]$. As in high-fidelity polymerases, Pol $\beta$ switches between an open and a closed state upon dNTP binding. This is accompanied by a closing movement of the thumb subdomain, with the $\alpha \mathrm{N}$ helix stacking against the plane of the template base and the incoming dNTP's base, and its Asn279 and Arg283 residues locking the base-binding pocket through interactions within the minor groove. In the binary complex, the template oxoG does not have a single conformation and is observed both in anti and in syn. As expected, binding dCTP confines oxoG to the anti conformation. Unlike in replicative polymerases, the template nucleotide's phosphate does not tightly interact with Pol $\beta$, allowing the phosphate to move away to relieve the clash with $\mathrm{O}^{8}$ while avoiding mismatch-like active site distortion. On the other hand, the incoming dATP fixes oxoG in the promutagenic syn conformation, additionally stabilized by an $\mathrm{O}^{8}$ [oxoG] ... N 1 1[Arg283] interaction. This contact is unique to oxoG(syn) and not observed with non-damaged guanine or oxoG(anti); in these latter cases, Arg283 interacts only with the nucleotide upstream of the templating nucleotide. However, the incoming dATP also have a tendency to stack over oxoG(anti), mimicking the A:G mismatch and preventing the thumb subdomain from closing. This configuration is observed in several Pol $\beta$ structures where the closed conformation is even slightly destabilized, for example, by lacking the $3^{\prime}-\mathrm{OH}$ in the primer or by the R283K mutation $[199,213]$. Indeed, Pol $\beta$ R298K shows decreased efficiency but increased fidelity for incorporation opposite oxoG [199]. Steered molecular dynamics suggests that closing on the oxoG(anti):dCTP is $\sim 2.4 \mathrm{kcal} / \mathrm{mol}$ more energetically favorable compared to oxoG(syn):dATP, mostly due to destabilizing interactions of the latter with Tyr271 [217,218]. The structures reflecting the extension of primers with C or A $3^{\prime}$-ends opposite oxoG, together with pre-steady-state kinetic studies, showed that a significant fraction of the next incoming dNTP docks in a catalytically unsuitable position at an angle with the template base, 
and is slowly equilibrated with the catalytically proficient coplanar orientation. This fraction is more abundant for the $3^{\prime}$-A primers, explaining their poorer extension efficiency [200].

Table 2. Activities of human X- and Y-family DNA polymerases opposite oxoG in vitro.

\begin{tabular}{|c|c|c|c|}
\hline Polymerase & $\begin{array}{l}\text { Efficiency of } \\
\text { oxoG Bypass }\end{array}$ & Efficiency of dNMPs Incorporation & $\begin{array}{l}\text { Efficiency of oxoG:C } \\
\text { and oxoG:A Extension }\end{array}$ \\
\hline Pol $\beta$ & $++[42,44]$ & $\begin{array}{c}\text { dCMP }>\text { dAMP }(4: 1)[42] \\
\text { dCMP }>\text { dAMP }(2: 1) \text { w/o PCNA [44,197,198] } \\
\text { dCMP }>\text { dAMP }(3: 1) \text { with PCNA [44] } \\
\text { dCMP } \sim \text { dAMP [201] }\end{array}$ & $\begin{array}{c}\text { oxoG:C > > oxoG:A }(15: 1) \\
{[200]}\end{array}$ \\
\hline $\operatorname{Pol} \lambda$ & $\begin{array}{c}+++ \\
{[71,198,202]}\end{array}$ & $\begin{array}{c}\text { dCMP > dAMP (12:1) w/o PCNA and (1200:1) with PCNA [44] } \\
\text { dAMP }>\text { dCMP [201] } \\
\text { dCMP } \sim \text { dAMP [198] } \\
\text { dCMP }<\text { dAMP }(1: 2 \text { to } 1: 4)[71,202]\end{array}$ & $\begin{array}{c}\text { oxoG:C > > oxoG:A } \\
{[71,202]}\end{array}$ \\
\hline Pol ı & $\begin{array}{c}+[203] \\
++[204,205]\end{array}$ & $\begin{array}{c}\mathrm{dCMP}>\mathrm{dAMP}>\mathrm{dTMP}(4: 2: 1)[203] \\
\mathrm{dGMP}>>\mathrm{dCMP}[204] \\
\mathrm{dCMP}>>\mathrm{dAMP}[72,201] \\
\mathrm{dGMP}>\mathrm{dCMP}>\mathrm{dTMP}>>\text { dAMP [206] } \\
\mathrm{dCMP}>\mathrm{dGMP}(2: 1) \text { w/o PCNA and }(5: 1) \text { with PCNA [44] } \\
\mathrm{dCMP}>\text { dGMP }(6: 1)>>\text { dAMP }>\text { dTMP } \\
{[\text { Makarova A.V., unpublished] }}\end{array}$ & $\begin{array}{l}\text { oxoG:C > oxoG:G [204] } \\
\text { oxoG:A > > oxoG:C > } \\
\text { oxoG:T > oxoG:G [206] }\end{array}$ \\
\hline Pol $\eta$ & $+++[207,208]$ & $\begin{array}{c}\mathrm{dCMP} \sim \mathrm{dAMP}>\mathrm{dGMP}(2: 2: 1)[208] \\
\mathrm{dCMP}>\mathrm{dAMP}(2.5: 1) \text { w/o PCNA and }(68: 1) \text { with PCNA [44] } \\
\mathrm{dCMP} \sim \mathrm{dAMP}[209] \\
\mathrm{dCMP}>>\mathrm{dAMP}[207] \\
\mathrm{dCMP}>\mathrm{dAMP}(4: 1)[73] \\
\mathrm{dAMP}>/ \sim \mathrm{dCMP}[72]\end{array}$ & $\begin{array}{c}\text { oxoG:C > oxoG:A [208] } \\
\text { oxoG:C oxoG:A [73] }\end{array}$ \\
\hline Pol $k$ & $\begin{array}{c}++[38,210] \\
+++[211]\end{array}$ & $\begin{array}{c}\text { dAMP }>\text { dCMP [72,211] } \\
\text { dAMP }>>\text { dCMP }(16: 1)[38] \\
\text { dAMP }>>\text { dCMP }(4-10: 1)[210] \\
\text { dAMP }>\text { dCMP }(3: 1)[212] \\
\text { dAMP }>>\text { dCMP [201] }\end{array}$ & $\begin{array}{c}\text { oxoG:T oxoG:C > } \\
\text { oxoG:A [38] } \\
\text { oxoG:C oxoG:A [210] }\end{array}$ \\
\hline
\end{tabular}

+ , low efficiency. ++, moderate efficiency. +++, high efficiency. "with PCNA", data for PCNA plus RPA.

\subsubsection{DNA Polymerase $\lambda$}

As noted above, oxoG in DNA has high mutagenic potential by mispairing with A. Post-replicative oxoG:A mispairs are removed by BER in a MutY/MUTYH-dependent fashion. Unlike OGG1-initated BER that requires Pol $\beta, \operatorname{Pol} \lambda$ seems to be involved in the MUTYH-initiated BER, which preferably proceeds through the long-patch pathway [41,44,50,219-221].

The efficiencies of incorporation of dCMP opposite to oxoG and undamaged G and of dAMP opposite to oxoG by Pol $\lambda$ are comparable, and misincorporation can occur $[71,198,202]$ (Table 2). However, Pol $\lambda$ extends from C:oxoG ten- to twentyfold better than from A:oxoG [71,202] and can catalyze the excision of dAMP base-paired to oxoG by pyrophosphorolysis [222], thus adding to the specificity of the GO system. In the presence of RPA and PCNA, Pol $\lambda$ is by far the most faithful pol in bypassing oxoG, incorporating dCMP 1,200-fold more efficiently than dAMP [44].

A recently solved series of crystal structures of Pol $\lambda$ fully characterize error-free oxoG bypass [71]. The structure that mimics the initial DNA-binding step surprisingly reveals that Pol $\lambda$ accommodates the oxoG strictly in the pro-mutagenic syn conformation, stabilized by Tyr505 and Arg517. Binding of oxoG in the anti conformation would lead to a clash of $\mathrm{O}^{8}$ with the $5^{\prime}$-posphate [71]. This sharply contrasts the dual oxoG accommodation mode characteristic of Pol $\beta$ [214]. However, in the crystal structures of Pol $\lambda$ with bound dNTPs, the active site allows formation of both oxoG(anti):C and oxoG(syn):A pairs, the former geometrically similar to canonical Watson-Crick base pairs, the latter making oxoG to protrude into a solvent-exposed DNA major groove. Thus, Pol $\lambda$ can place oxoG in the catalytically competent conformation with both incoming dCTP and dATP without significant structure distortion, which could partially explain its low C-vs-A insertion specificity. On the contrary, 
the structures that mimic the extension step show that the Glu529 residue in the SD2 region of the thumb domain forms a specific hydrogen bond with oxoG(anti) and selectively stabilizes C:oxoG(anti) while destabilizing A:oxoG(syn) terminal pairs. Mutations at Glu529 do not affect polymerization kinetics on undamaged substrates, whereas Pol $\lambda$ E529A shows decreased catalytic efficiency of extension from C:oxoG and enhanced extension from A:oxoG [71].

Consistent with a role of $\mathrm{Pol} \lambda$ in the oxoG bypass, mammalian cells deficient in Pol $\lambda$ display reduced TLS activity past oxoG and increased mutagenesis [41,50,223] (Table 3). Remarkably, the $\mathrm{G}: \mathrm{C} \rightarrow \mathrm{T}: \mathrm{A}$ transversion rate is not affected in these cells, whereas $\mathrm{G}: \mathrm{C} \rightarrow \mathrm{C}: \mathrm{G}$ mutations [41], small deletions $[41,50]$ as well as $\mathrm{G}: \mathrm{C} \rightarrow \mathrm{A}: \mathrm{T}$ mutations at untargeted $\mathrm{G}: \mathrm{C}$ sites [223] were reported. It is likely that in the absence of Pol $\lambda$, other polymerase(s) bypass oxoG in the MUTYH-initiated BER pathway, preventing $\mathrm{G}: \mathrm{C} \rightarrow \mathrm{T}: \mathrm{A}$ transversions but promoting other types of mutations.

Table 3. Activities of human X- and Y-family DNA polymerases opposite oxoG in shuttle plasmid in mammalian cells.

\begin{tabular}{|c|c|}
\hline Polymerase & Role in oxoG-Induced Mutagenesis in Cells \\
\hline Pol $\lambda$ & $\begin{array}{l}\text { prevents oxoG-induced mutagenesis but knockdown does not affect } \mathrm{G}: \mathrm{C} \rightarrow \mathrm{T}: \mathrm{A} \\
\text { transversions rate }[41,50,223]\end{array}$ \\
\hline Pol $\eta$ & prevents oxoG-induced mutagenesis $[37,224,225]$ \\
\hline Pol ı & $\begin{array}{l}\text { downregulation is associated with increased cell sensitivity to oxidative damage [226] } \\
\text { but has no effect on oxoG-induced mutagenesis [225] }\end{array}$ \\
\hline Pol $k$ & knockdown decreases oxoG-induced mutagenesis [227] \\
\hline
\end{tabular}

\subsection{Y-family DNA Polymerases}

Y-family Pol $\iota$, Pol $\eta$, Pol $\kappa$ and B-family Pol $\zeta$ play a crucial role in replication through non-bulky DNA lesions in human cells [reviewed in [228-231]]. Pol $\iota$, Pol $\eta$, and Pol $\kappa$ lack strict structural requirements to the DNA template. These polymerases efficiently incorporate nucleotides opposite a variety of DNA lesions and act as "polymerases-inserters" [230]. According to the two-polymerase model, elongation from primer termini paired with damaged nucleobases is carried out by a "polymerase-extender" Pol $\zeta[232,233]$. Pol $\iota$, Pol $\eta$, and Pol $k$ efficiently bypass oxoG in vitro (Table 2) and possibly contribute to the TLS past oxoG in vivo.

\subsubsection{DNA Polymerase เ}

Pol ı has a very low accuracy of DNA synthesis [234,235]. Remarkably, Pol ı preferably incorporates dGMP opposite templates $\mathrm{T}$ and $\mathrm{U}$. It was suggested that the unique misinsertion specificity of Pol $\iota$ may decrease the mutagenic potential of deaminated C [204]. Pol ı bypasses a variety of DNA lesions with different accuracies and efficiencies [reviewed in [228]]. Like Pol $\beta$ and Pol $\lambda$, Pol $\iota$ also possesses the dRP-lyase activity [236,237].

Pol ı preferably incorporates complementary dCMP opposite oxoG, though the efficiency of nucleotide incorporation is decreased (Table 2) [44,72,203]. Interestingly, two studies reported preferential incorporation of dGMP opposite oxoG [204,206]. It is likely, that the accuracy of oxoG bypass is sequence-dependent.

The specific translesion activities of $\mathrm{Pol} \iota$ are determined by a unique narrow active site. The short $C 1^{\prime}-C 1^{\prime}$ distance between templating and incoming nucleotides $(<9 \AA)$ interferes with the formation of canonical WC base pairs (required $\sim 10 \AA \mathrm{C} 1^{\prime}-\mathrm{C} 1^{\prime}$ distance) [238-240]. When replicating opposite template purines, Pol ı uses HG base pairing to fit the nascent base pair in the active site $[238,239,241,242]$. Purines are fixed in the syn-conformation even if WC pairing is energetically more favorable (e.g., WC (anti)G:(anti)dCMP pair forms three H-bonds while HG (syn)G:(anti)dCMP pair forms two H-bonds and requires protonation of the incoming dCTP) $[205,239]$. HG interactions allow Pol ı to 
efficiently bypass DNA lesions blocking the WC base pairs formation such as $1, \mathrm{~N}^{6}$-etheno-A and $\mathrm{N}^{2}-\mathrm{G}$ adducts [reviewed in [228]].

Like undamaged G, oxoG preferentially adopts the syn-conformation in the active site of Pol $\mathrm{l}$. Importantly, the incoming dATP and dGTP are also forced to adopt the syn-conformation to fit in the narrow active site and form only one H-bond with oxoG (Figure 2C). The smaller incoming pyrimidine dTTP and dCTP adopt the anti conformation but only dCTP forms the strong linear H-bond network with the HG edge of oxoG (Figure 2C) resulting in relatively efficient and precise lesion bypass [72].

It was also shown that the Q59 residue influences nucleotide selection and bypass efficiency opposite oxoG [72]. The repulsion between the O8 atom of oxoG and the OE1 atom of Q59 results in a tilting of the oxoG base by $30^{\circ}$ towards the major groove of DNA. This partially destabilizes the syn-conformation of oxoG and possibly explains decreased efficiency of DNA synthesis opposite oxoG compared with undamaged G. The Q59A substitution increases the efficiency of nucleotide incorporation opposite oxoG but reduces the accuracy nucleotide incorporation opposite the lesion. It is likely that the Q59A substitution enlarges the active site cavity which promotes the binding of dATP in the anti conformation [72].

The role of Pol $\iota$ in TLS opposite oxoG is not established yet. Pol $\iota$ is recruited to the sites of oxidative DNA damage and downregulation of $\mathrm{Pol} \iota$ is associated with increased cell sensitivity to oxidative damage in human MRC5-SV fibroblasts [226] suggesting that Pol ı might play a protective role against the oxoG-induced mutagenesis in cells. However, downregulation of Pol $\iota$ in 293T cells has no effect on the oxoG induced mutagenesis in shuttle plasmid with the site-specific oxoG lesion [225] (Table 3). Additional studies with single POLI knockouts and double POLI/OGG1, POLI/POLL and POLI/POLH knockouts are required to reveal the role of Pol $\iota$ in TLS past oxoG.

\subsubsection{DNA Polymerase $\eta$}

Eukaryotic Pol $\eta$ effectively bypasses cyclobutane pyrimidine dimers with relatively high accuracy and plays a key role in cell protection against UV-induced mutagenesis $[243,244]$. In vitro Pol $\eta$ replicates through a wide range of DNA lesions including oxoG [44,73,207-209,245-249] (Table 2).

In yeast, Pol $\eta$ suppresses the ogg1-dependent mutagenesis $[207,250,251]$ and inserts complementary dCMP opposite oxoG $[207,209,252]$. Human cells deficient in Pol $\eta$ also show the increased level of the oxoG-induced mutagenesis $[37,224,225]$ though Pol $\eta$ was found not to be essential for oxoG bypass [37]. Importantly, the levels of the oxoG-induced mutagenesis in the single Pol $\eta$-deficient and Pol $\zeta$-deficient and double Pol $\eta$-Pol $\zeta$ deficient cells are similar suggesting that two DNA polymerases work in the same TLS pathway [225].

Human Pol $\eta$ preferably incorporates dCMP opposite oxoG in vitro in many studies (Table 2) $[44,73,207]$ while some studies reported that human Pol $\eta$ is less accurate opposite oxoG than yeast enzyme (Table 2) [72,208,209]. It is likely that the spectrum of nucleotide incorporation of Pol $\eta$ opposite oxoG varies widely depending on the sequence context [253]. Moreover, the accuracy of Pol $\eta$ is modulated by accessory proteins. In vitro, human Pol $\eta$ showed a much higher bypass efficiency and accuracy for the oxoG lesion in the presence of PCNA and RPA [44].

The structures of human Pol $\eta$ in complexes with templating oxoG and incoming dCMPNPP, dAMPNPP and dGMPNPP were recently solved [73]. oxoG in the anti-confomation establishes three H-bonds with C, while oxoG in the syn-conformation forms two H-bonds with A (Figure 2D) and G. In all Pol $\eta$ structures, the fingers domain amino acids Gln38 and Arg61 are engaged in contacts to the nascent base pair. Gln38 forms an H-bond with the N3 atom of oxoG in the anti conformation (in a complex with dCMPNPP) and with the $\mathrm{O}^{8}$ atom of oxoG in the syn-conformation (in complexes with dAMPNPP and dGMPNPP) [73]. Therefore, unlike Pol $\iota$, Pol $\eta$ does not rely on the stabilization of oxoG in the syn-conformation to maintain the accuracy of oxoG bypass. Arg61 forms an H-bond to the phosphate group of dCMPNPP and dAMPNPP. However, Arg61 is involved in a unique stacking interaction with $\mathrm{C}$ base of the incoming nucleotide which can facilitate its accommodation and stabilize its orientation opposite the lesion (Figure 2D) [73]. Importantly, dGMPNPP is shifted in the active site 
and the position of its phosphate group is less favorable for the 3-OH nucleophilic attack [73]. It is also likely that $\mathrm{H}$-bonds between bases contribute to the accurate oxoG bypass by Pol $\eta$ : while $\mathrm{A}$ and $\mathrm{G}$ bases form two H-bonds with oxoG, the oxoG:C pair is stabilized with three bonds leading to the preferential incorporation of complementary nucleotide opposite the lesion.

\subsubsection{DNA Polymerase $\mathrm{k}$}

Pol $\mathrm{k}$ efficiently and accurately bypasses bulky $\mathrm{N}^{2}$-G adducts formed under exposure to some carcinogens [254-256] and relatively non-bulky replication-blocking lesions such as $1, N^{2}-\varepsilon G$, $N^{2}, 3-\varepsilon G[257,258]$ and thymine glycol [259]. However, unlike other members of Y-family, Pol k replicates through oxoG in a highly error-prone manner preferably incorporating dAMP opposite the lesion (Table 2) [38,210-212]. In agreement with biochemical studies, the role of Pol $\mathrm{K}$ in the oxoG-induced GC $\rightarrow$ TA mutagenesis was demonstrated in human U2OS cells [227].

The exact structural mechanism of Pol $\mathrm{k}$ preference for the incorporation of dAMP over dCMP is not clear since the crystals of Pol $\kappa$ complex with the oxoG:C pair is difficult to grow [210]. However, it was shown that the Pol $\mathrm{k}$ active site is very well-adapted to accommodate oxoG in the syn-conformation for base pairing with incoming anti-dATP in a HG fashion [210,260]. It was suggested that the rotation of oxoG to the syn-conformation is likely a consequence of the steric clash between the $\mathrm{O}^{8}$ atom of oxoG and the template phosphate backbone [260]. The interactions of a unique N-clasp domain of Pol $\mathrm{k}$ with the phosphate and the nucleotide $5^{\prime}$ to oxoG possibly also favor the syn-conformation of oxoG in Pol k [260].

\section{Incorporation of oxodGMP in DNA}

OxodGTP, a major oxidized nucleotide in the cell, is capable of mispairing with templating A yielding A:T $\rightarrow C: G$ transversions [85]. Incorporation of oxodGTP by mammalian DNA polymerases is not yet extensively characterized in vitro, in vivo and structurally. Studies suggest that high-fidelity DNA polymerases are able to discriminate against oxodGTP. Pol $\delta$ incorporates oxodGTP opposite $A$ and $C$ with almost equal efficiencies but incorporation of oxodGTP is 3 orders of magnitude lower than for dGTP incorporation opposite C [43]. Pol $\alpha$ incorporates oxodGMP opposite $C$ and A 300-500 times less efficient than incorporates dGMP opposite $C$ and demonstrates a 5-fold preference for oxodGMP insertion opposite C over A [261]. However, repair and TLS DNA polymerases might poorly discriminate against oxodGTP and polymerize oxodGTP with higher error-rates.

In contrast to the incorporation opposite oxoG, X-family Pol $\beta$ and Pol $\lambda$ have a clear preference both for forming pro-mutagenic A:oxoG pairs with the oxodGTP substrate $[197,198,262-264]$ and for extension from such primer termini [265]. Pol $\beta$ and Pol $\lambda$ incorporate oxodGMP opposite A with 11-40-fold preference over C $[197,198,262-264]$. However, Pol $\beta$ and Pol $\lambda$ show reduced polymerase activity when incorporating oxodGMP. Incorporation of oxodGMP opposite A and C is 12-130 fold less efficient than incorporation of dGMP opposite $C$ in Pol $\beta$ and is 214-7500 less efficient in Pol $\lambda$ [198].

Like Pol $\beta$ and Pol $\lambda$, Y-family Pol $\kappa$ incorporates oxodGTP opposite A with $\sim 10$ fold preference over $C$ and demonstrates very low efficiency (oxidation of dGTP decreases the efficiency of nucleotide incorporation opposite $A$ and $C$ for 150 and 1000 fold respectively) [266]. In contrast, Pol $\eta$ and Pol $\iota$ almost exclusively misincorporates oxodGMP opposite template A [266-268]. The efficiency of oxodGMP polymerization across A is 30-50-fold and only 2-7-fold lower than dTMP opposite A in Pol $\iota$ and in Pol $\eta$ respectively $[266,268]$. Moreover, Pol $\eta$ readily extends the $3{ }^{\prime}-8$ oxodG containing primers (preferentially A:oxodGMP) [268].

Given the low efficiency of oxodGMP incorporation and a very small fraction of the cell's DNA is synthesized, the role of Pol $\lambda$ and Pol $\kappa$ (and possibly Pol $\beta$ and Pol $\iota$ ) in oxodGTP induced mutagenesis is not likely to be of biological significance. However, the role of Pol $\eta$ in oxodGTP-induced A:T $\rightarrow C: G$ transversions was clearly demonstrated in Pol $\eta$ knockdown 293T cells with the shuttle plasmid assay [269]. It was also shown that Rev1 and Pol $\zeta$ knock-downs affect the rate of oxodGTP-induced $A: T \rightarrow C: G$ transversions [269]. The potential mutagenic risk from misincorporation of oxodGMP is 
likely alleviated by restricting specialized DNA polymerases to very specific function with only a minor fraction of genomic nucleotides incorporated.

Pol $\beta$ and Pol $\lambda$ are among few polymerases for which incorporation of oxodGMP has been structurally characterized [262-265]. These structures illuminate general principles of non-mutagenic and mutagenic oxodGMP insertion and extension. In the structures with the incoming oxodGTP in a precatalytic state, the damaged dNTP adopts the syn conformation and forms a Hoogsteen pair with A in the template.

In Pol $\beta$, the steric clash of $\mathrm{O}^{8}$ with phosphate in ant $i$ is less well tolerated in the incoming oxodGTP than in the template oxodGMP, and requires a third metal ion in the active site (the "product metal", transiently observed in Pol $\beta$ only after the insertion of the correct nucleotide $[60,264]$ to accommodate the $\alpha$ phosphate in a position required for catalysis). After the incorporation and polymerase complex opening, oxoG tends to unpair from $C$ and stack over it. When oxodGMP(anti) is at the end of the primer, intrusion of $\mathrm{O}^{8}$ disrupts the Arg254 ... Asp256 salt bridge that stabilizes the phosphate of the $3^{\prime}$-terminal nucleotide. Overall, the error-prone incorporation of oxodGMP opposite to A mostly arises from the destabilizing effect of $\mathrm{O}^{8}$ - phosphate interactions in anti both at the insertion and the extension steps. The geometry of the A:oxodGMP mispair also causes some polymerase structure distortions in Pol $\lambda$ but it still can be accommodated into the active site without major conformational rearrangements [263].

The role of the single active site residues in the stabilization of the mutagenic syn conformation of oxodGTP was also demonstrated in Pol $\beta$ (Asn279) [197,198], Pol $\lambda$ (Asn513) [263], Pol $\eta$ (Arg61) and Pol k (Tyr112) [266]. These residues are located in distinct positions in the active sites and modulate oxodGTP incorporation by different ways. In Pol $\beta$, the side chain of Asn279 favorably interacts with oxodGTP in the syn conformation by making a hydrogen bond with $\mathrm{O}^{8}[197,198]$. The oxodGTP syn conformation is stabilized by a hydrogen bond with Asn513 in Pol $\lambda$; the N513A mutant inserts oxodGMP opposite A 25 -fold less efficiently than wild-type Pol $\lambda$. However, this stabilizing effect is relatively small compared with the homologous Pol $\beta$ Asn249 residue, which, when mutated, shows a 1000-fold effect on oxodGMP incorporation [184]. Modeling oxodGTP in the active site of Pol $\eta$ suggested that the side chain of Arg61 disturbs the formation of the anti conformation and thus enhances the formation of the syn conformation of oxodGTP [266]. It was suggested that the steric gate Tyr112 residue in Pol $\mathrm{k}$ might interact with the sugar and/or base of the incoming oxodGTP forcing it the syn conformation [266].

\section{Conclusions}

Among many DNA damaging agents, ROS are the most important for aerobic organisms. oxoG is one of the best characterized oxidative DNA lesions. Given the dual coding properties and abundance, oxoG presents a serious challenge to maintain the genomic integrity in cells.

The structures of many DNA repair enzymes dealing with oxoG in DNA and in the nucleotide pool are known, and they reveal a surprising diversity in the mode of recognition of this lesion. OxoG can be bound either in anti or in syn conformation, and can be stabilized via bonds to different atoms of this nucleobase. The interactions that distinguish oxoG from $\mathrm{G}$ are theoretically possible through $\mathrm{N} 7$ and $\mathrm{O}^{8}$, but only the former option is realized in the structures known at the moment. No common oxoG-recognizing structural motif in proteins of different families can be defined. Moreover, structural and modeling studies of DNA glycosylases suggest that they employ multiple conformational checkpoints to assure that only oxoG, but not normal G, is extruded all the way from the DNA duplex to the enzyme's active site. In MutY/MUTYH DNA glycosylases, early recognition steps are not yet characterized structurally, and it remains to be seen whether these enzymes can use the NUDIX domain or the FeS cluster to detect oxoG while scanning DNA for the A:oxoG mismatch.

The role of several DNA polymerases in error-free and error-prone TLS across oxoG was established in vitro and in model cell lines. The accuracy of dNMPs incorporation opposite oxoG is polymerase dependent. The structural studies revealed high divergence in the mechanisms of oxoG bypass among 
repair and TLS DNA polymerases. At the same time, the structural basis of nucleotide incorporation by high-fidelity eukaryotic DNA polymerases is yet to be determined.

Remarkably, the accuracy of dNMPs incorporation opposite oxoG is modulated by replicative accessory factors. PCNA and RPA moderately increase the efficiency of dCMP incorporation of Pol $\delta$, Pol $\iota$ and Pol $\eta[43,44]$ and dramatically enhance dCMP incorporation of Pol $\lambda[44]$ opposite oxoG in vitro. PCNA was also found to be an essential component for efficient base pair extension beyond the lesion by Pol $\delta[43,44]$. However, the mechanism of PCNA-dependent modulation of the accuracy of oxoG bypass also remains elusive.

Another unanswered question is the actual process of DNA polymerase switching during TLS past oxoG lesion. oxoG is not considered as a blocking lesion per se whereas a switch from a high-fidelity DNA polymerase to a specialized DNA polymerase is triggered by stalling of replication fork at DNA damage site. Nevertheless, it was suggested that pausing of Pol $\delta$ in front of the lesion and difficulties in extending from the correct oxoG:C base pair can be sufficient to facilitate DNA polymerase switching [41]. It is possible that DNA and polymerase active site distortions similar with revealed in the G. stearothermophilus Pol I structure with oxoG:C pair [69] can provide a basis for oxoG:C recognition by a specialized DNA polymerase and facilitate polymerase switching to extend the correct oxoG:C pair. It cannot be excluded that the local destabilizing effect of oxoG on DNA [74,75] and less stable base pairing [68] might also promote a high-fidelity polymerase pausing and switching to a specialized DNA polymerase during replication and TLS. In MUTYH-dependent BER pathway, recruitment of specialized DNA polymerases to the oxoG or oxoG:A lesion sites can be mediated by specific protein-protein interactions with repair enzymes and regulatory factors. Finally, post-translational modifications and/or accumulation of repair and TLS DNA polymerases on chromatin under oxidative stress might also control their recruitment to the sites of oxoG lesions. The biological relevance of these hypotheses is yet to be verified.

Author Contributions: Writing—original draft preparation, A.V.Y., E.S.S., A.V.E., A.V.M., D.O.Z.; writing一review and editing, A.V.M., D.O.Z.; visualization, E.S.S., D.O.Z.; funding acquisition, A.V.M., D.O.Z.

Funding: This research was funded by the RFBR grants 17-00-00264 (to A.V.M.) and 17-00-00261 (to D.O.Z.). Partial salary support from Russian Ministry of Science and Education (6.5773.2017/6.7 to D.O.Z and VI.62.1.5 0309-2019-0003 to D.O.Z., A.V.E., and A.V.Y.).

Conflicts of Interest: The authors declare no conflict of interest.

\section{References}

1. Kasai, H.; Tanooka, H.; Nishimura, S. Formation of 8-hydroxyguanine residues in DNA by X-irradiation. Gann 1984, 75, 1037-1039. [PubMed]

2. Jovanovic, S.V.; Simic, M.G. One-electron redox potentials of purines and pyrimidines. J. Phys. Chem. 1986, 90, 974-978. [CrossRef]

3. Kasai, H.; Crain, P.F.; Kuchino, Y.; Nishimura, S.; Ootsuyama, A.; Tanooka, H. Formation of 8-hydroxyguanine moiety in cellular DNA by agents producing oxygen radicals and evidence for its repair. Carcinogenesis 1986, 7, 1849-1851. [CrossRef]

4. Subramanian, P.; Dryhurst, G. Electrochemical oxidation of guanosine: Formation of some novel guanine oligonucleosides. J. Electroanal. Chem. Interfacial Electrochem. 1987, 224, 137-162. [CrossRef]

5. Steenken, S.; Jovanovic, S.V. How easily oxidizable is DNA? One-electron reduction potentials of adenosine and guanosine radicals in aqueous solution. J. Am. Chem. Soc. 1997, 119, 617-618. [CrossRef]

6. van Loon, B.; Markkanen, E.; Hübscher, U. Oxygen as a friend and enemy: How to combat the mutational potential of 8-oxo-guanine. DNA Repair 2010, 9, 604-616. [CrossRef] [PubMed]

7. Agnez-Lima, L.F.; Melo, J.T.A.; Silva, A.E.; Oliveira, A.H.S.; Timoteo, A.R.S.; Lima-Bessa, K.M.; Martinez, G.R.; Medeiros, M.H.G.; Di Mascio, P.; Galhardo, R.S.; et al. DNA damage by singlet oxygen and cellular protective mechanisms. Mutat. Res. 2012, 751, 15-28. [CrossRef] [PubMed]

8. Burrows, C.J.; Muller, J.G. Oxidative nucleobase modifications leading to strand scission. Chem. Rev. 1998, 98, 1109-1151. [CrossRef] [PubMed] 
9. Steenken, S. Purine bases, nucleosides and nucleotides: Aqueous solution redox chemistry and transformation of their radical cations and $\mathrm{e}^{-}$and $\mathrm{OH}$ adducts. Chem. Rev. 1989, 89, 503-520. [CrossRef]

10. Helbock, H.J.; Beckman, K.B.; Shigenaga, M.K.; Walter, P.B.; Woodall, A.A.; Yeo, H.C.; Ames, B.N. DNA oxidation matters: The HPLC-electrochemical detection assay of 8-oxo-deoxyguanosine and 8-oxo-guanine. Proc. Natl Acad. Sci. USA 1998, 95, 288-293. [CrossRef]

11. Collins, A.R. Oxidative DNA damage, antioxidants, and cancer. Bioessays 1999, 21, 238-246. [CrossRef]

12. Lindahl, T.; Barnes, D.E. Repair of endogenous DNA damage. Cold Spring Harb. Symp. Quant. Biol. 2000, 65, 127-133. [CrossRef]

13. Friedberg, E.C.; Walker, G.C.; Siede, W.; Wood, R.D.; Schultz, R.A.; Ellenberger, T. DNA Repair and Mutagenesis; ASM Press: Washington, DC, USA, 2006; 1118p.

14. Møller, P.; Cooke, M.S.; Collins, A.; Olinski, R.; Rozalski, R.; Loft, S. Harmonising measurements of 8-oxo-7,8-dihydro-2'-deoxyguanosine in cellular DNA and urine. Free Radic. Res. 2012, 46, 541-553. [CrossRef]

15. ESCODD (European Standards Committee on Oxidative DNA Damage); Gedik, C.M.; Collins, A. Establishing the background level of base oxidation in human lymphocyte DNA: Results of an interlaboratory validation study. FASEB J. 2005, 19, 82-84. [CrossRef] [PubMed]

16. Swenberg, J.A.; Lu, K.; Moeller, B.C.; Gao, L.; Upton, P.B.; Nakamura, J.; Starr, T.B. Endogenous versus exogenous DNA adducts: Their role in carcinogenesis, epidemiology, and risk assessment. Toxicol. Sci. 2011, 120, S130-S145. [CrossRef] [PubMed]

17. Helbock, H.J.; Beckman, K.B.; Ames, B.N. 8-Hydroxydeoxyguanosine and 8-hydroxyguanine as biomarkers of oxidative DNA damage. Methods Enzymol. 1999, 300, 156-166. [PubMed]

18. Valavanidis, A.; Vlachogianni, T.; Fiotakis, C. 8-hydroxy-2'-deoxyguanosine (8-OHdG): A critical biomarker of oxidative stress and carcinogenesis. J. Environ. Sci. Health C Environ. Carcinog. Ecotoxicol. Rev. 2009, 27, 120-139. [CrossRef]

19. Wood, M.L.; Esteve, A.; Morningstar, M.L.; Kuziemko, G.M.; Essigmann, J.M. Genetic effects of oxidative DNA damage: Comparative mutagenesis of 7,8-dihydro-8-oxoguanine and 7,8-dihydro-8-oxoadenine in Escherichia coli. Nucleic Acids Res. 1992, 20, 6023-6032. [CrossRef] [PubMed]

20. Moriya, M. Single-stranded shuttle phagemid for mutagenesis studies in mammalian cells: 8-oxoguanine in DNA induces targeted G.C $\rightarrow$ T.A transversions in simian kidney cells. Proc. Natl Acad. Sci. USA 1993, 90, 1122-1126. [CrossRef]

21. Burrows, C.J.; Muller, J.G.; Kornyushyna, O.; Luo, W.; Duarte, V.; Leipold, M.D.; David, S.S. Structure and potential mutagenicity of new hydantoin products from guanosine and 8-oxo-7,8-dihydroguanine oxidation by transition metals. Environ. Health Perspect. 2002, 110, 713-717. [CrossRef] [PubMed]

22. Niles, J.C.; Wishnok, J.S.; Tannenbaum, S.R. Spiroiminodihydantoin and guanidinohydantoin are the dominant products of 8-oxoguanosine oxidation at low fluxes of peroxynitrite: Mechanistic studies with ${ }^{18} \mathrm{O}$. Chem. Res. Toxicol. 2004, 17, 1510-1519. [CrossRef] [PubMed]

23. Koizume, S.; Inoue, H.; Kamiya, H.; Ohtsuka, E. Neighboring base damage induced by permanganate oxidation of 8-oxoguanine in DNA. Nucleic Acids Res. 1998, 26, 3599-3607. [CrossRef]

24. Kim, J.-E.; Choi, S.; Yoo, J.-A.; Chung, M.-H. 8-oxoguanine induces intramolecular DNA damage but free 8-oxoguanine protects intermolecular DNA from oxidative stress. FEBS Lett. 2004, 556, 104-110. [CrossRef]

25. Burgers, P.M.J.; Kunkel, T.A. Eukaryotic DNA replication fork. Annu. Rev. Biochem. 2017, 86, 417-438. [CrossRef] [PubMed]

26. Kunkel, T.A. Evolving views of DNA replication (in)fidelity. Cold Spring Harb. Symp. Quant. Biol. 2009, 74, 91-101. [CrossRef] [PubMed]

27. Rothwell, P.J.; Waksman, G. Structure and mechanism of DNA polymerases. Adv. Protein Chem. 2005, 71, 401-440. [PubMed]

28. Bębenek, A.; Ziuzia-Graczyk, I. Fidelity of DNA replication-A matter of proofreading. Curr. Genet. 2018, 64, 985-996.

29. Jain, R.; Aggarwal, A.K.; Rechkoblit, O. Eukaryotic DNA polymerases. Curr. Opin. Struct. Biol. 2018, 53,77-87. [CrossRef]

30. Masutani, C.; Araki, M.; Yamada, A.; Kusumoto, R.; Nogimori, T.; Maekawa, T.; Iwai, S.; Hanaoka, F. Xeroderma pigmentosum variant $(\mathrm{XP}-\mathrm{V})$ correcting protein from HeLa cells has a thymine dimer bypass DNA polymerase activity. EMBO J. 1999, 18, 3491-3501. [CrossRef] [PubMed] 
31. Aller, P.; Rould, M.A.; Hogg, M.; Wallace, S.S.; Doublié, S. A structural rationale for stalling of a replicative DNA polymerase at the most common oxidative thymine lesion, thymine glycol. Proc. Natl Acad. Sci. USA 2007, 104, 814-818. [CrossRef]

32. Liao, S.; Matsumoto, Y.; Yan, H. Biochemical reconstitution of abasic DNA lesion replication in Xenopus extracts. Nucleic Acids Res. 2007, 35, 5422-5429. [CrossRef]

33. Schmitt, M.W.; Matsumoto, Y.; Loeb, L.A. High fidelity and lesion bypass capability of human DNA polymerase $\delta$. Biochimie 2009, 91, 1163-1172. [CrossRef]

34. Locatelli, G.A.; Pospiech, H.; Tanguy Le Gac, N.; van Loon, B.; Hubscher, U.; Parkkinen, S.; Syväoja, J.E.; Villani, G. Effect of 8-oxoguanine and abasic site DNA lesions on in vitro elongation by human DNA polymerase $\varepsilon$ in the presence of replication protein A and proliferating-cell nuclear antigen. Biochem. J. 2010, 429, 573-582. [CrossRef]

35. Weerasooriya, S.; Jasti, V.P.; Basu, A.K. Replicative bypass of abasic site in Escherichia coli and human cells: Similarities and differences. PLoS ONE 2014, 9, e107915. [CrossRef] [PubMed]

36. Ignatov, A.V.; Bondarenko, K.A.; Makarova, A.V. Non-bulky lesions in human DNA: The ways of formation, repair, and replication. Acta Naturae 2017, 9, 12-26. [CrossRef]

37. Avkin, S.; Livneh, Z. Efficiency, specificity and DNA polymerase-dependence of translesion replication across the oxidative DNA lesion 8-oxoguanine in human cells. Mutat. Res. 2002, 510, 81-90. [CrossRef]

38. Haracska, L.; Prakash, L.; Prakash, S. Role of human DNA polymerase $k$ as an extender in translesion synthesis. Proc. Natl Acad. Sci. USA 2002, 99, 16000-16005. [CrossRef]

39. Jałoszyński, P.; Masutani, C.; Hanaoka, F.; Perez, A.B.; Nishimura, S. 8-Hydroxyguanine in a mutational hotspot of the c-Ha-ras gene causes misreplication, 'action-at-a-distance' mutagenesis and inhibition of replication. Nucleic Acids Res. 2003, 31, 6085-6095. [CrossRef]

40. Meng, X.; Zhou, Y.; Zhang, S.; Lee, E.Y.C.; Frick, D.N.; Lee, M.Y.W.T. DNA damage alters DNA polymerase $\delta$ to a form that exhibits increased discrimination against modified template bases and mismatched primers. Nucleic Acids Res. 2009, 37, 647-657. [CrossRef]

41. Markkanen, E.; Castrec, B.; Villani, G.; Hübscher, U. A switch between DNA polymerases $\delta$ and $\lambda$ promotes error-free bypass of 8-oxo-G lesions. Proc. Natl Acad. Sci. USA 2012, 109, 20401-20406. [CrossRef]

42. Shibutani, S.; Takeshita, M.; Grollman, A.P. Insertion of specific bases during DNA synthesis past the oxidation-damaged base 8-oxodG. Nature 1991, 349, 431-434. [CrossRef] [PubMed]

43. Einolf, H.J.; Guengerich, F.P. Fidelity of nucleotide insertion at 8-oxo-7,8-dihydroguanine by mammalian DNA polymerase $\delta$ : Steady-state and pre-steady-state kinetic analysis. J. Biol. Chem. 2001, 276, 3764-3771. [CrossRef] [PubMed]

44. Maga, G.; Villani, G.; Crespan, E.; Wimmer, U.; Ferrari, E.; Bertocci, B.; Hübscher, U. 8-oxo-guanine bypass by human DNA polymerases in the presence of auxiliary proteins. Nature 2007, 447, 606-608. [CrossRef]

45. Fazlieva, R.; Spittle, C.S.; Morrissey, D.; Hayashi, H.; Yan, H.; Matsumoto, Y. Proofreading exonuclease activity of human DNA polymerase $\delta$ and its effects on lesion-bypass DNA synthesis. Nucleic Acids Res. 2009, 37, 2854-2866. [CrossRef] [PubMed]

46. Yasui, M.; Kanemaru, Y.; Kamoshita, N.; Suzuki, T.; Arakawa, T.; Honma, M. Tracing the fates of site-specifically introduced DNA adducts in the human genome. DNA Repair 2014, 15, 11-20. [CrossRef]

47. Le Page, F.; Guy, A.; Cadet, J.; Sarasin, A.; Gentil, A. Repair and mutagenic potency of 8-oxoG:A and 8-oxoG:C base pairs in mammalian cells. Nucleic Acids Res. 1998, 26, 1276-1281. [CrossRef] [PubMed]

48. Sunaga, N.; Kohno, T.; Shinmura, K.; Saitoh, T.; Matsuda, T.; Saito, R.; Yokota, J. OGG1 protein suppresses $\mathrm{G}: \mathrm{C} \rightarrow \mathrm{T}:$ A mutation in a shuttle vector containing 8-hydroxyguanine in human cells. Carcinogenesis 2001, 22, 1355-1362. [CrossRef]

49. Yamane, A.; Shinmura, K.; Sunaga, N.; Saitoh, T.; Yamaguchi, S.; Shinmura, Y.; Yoshimura, K.; Murakami, H.; Nojima, Y.; Kohno, T.; et al. Suppressive activities of OGG1 and MYH proteins against G:C to T:A mutations caused by 8 -hydroxyguanine but not by benzo[a]pyrene diol epoxide in human cells in vivo. Carcinogenesis 2003, 24, 1031-1037. [CrossRef] [PubMed]

50. Pande, P.; Haraguchi, K.; Jiang, Y.-L.; Greenberg, M.M.; Basu, A.K. Unlike catalyzing error-free bypass of 8-oxodGuo, DNA polymerase $\lambda$ is responsible for a significant part of Fapy·dG-induced $G \rightarrow$ T mutations in human cells. Biochemistry 2015, 54, 1859-1862. [CrossRef] 
51. Xie, Y.; Yang, H.; Cunanan, C.; Okamoto, K.; Shibata, D.; Pan, J.; Barnes, D.E.; Lindahl, T.; McIlhatton, M.; Fishel, R.; et al. Deficiencies in mouse Myh and $O g g 1$ result in tumor predisposition and G to T mutations in codon 12 of the K-ras oncogene in lung tumors. Cancer Res. 2004, 64, 3096-3102. [CrossRef] [PubMed]

52. Ohno, M.; Sakumi, K.; Fukumura, R.; Furuichi, M.; Iwasaki, Y.; Hokama, M.; Ikemura, T.; Tsuzuki, T.; Gondo, Y.; Nakabeppu, Y. 8-oxoguanine causes spontaneous de novo germline mutations in mice. Sci. Rep. 2014, 4, 4689. [CrossRef] [PubMed]

53. Viel, A.; Bruselles, A.; Meccia, E.; Fornasarig, M.; Quaia, M.; Canzonieri, V.; Policicchio, E.; Urso, E.D.; Agostini, M.; Genuardi, M.; et al. A specific mutational signature associated with DNA 8-oxoguanine persistence in MUTYH-defective colorectal cancer. EBioMedicine 2017, 20, 39-49. [CrossRef]

54. Sugiyama, H.; Saito, I. Theoretical studies of GG-specific photocleavage of DNA via electron transfer: Significant lowering of ionization potential and 5'-localization of HOMO of stacked GG bases in B-form DNA. J. Am. Chem. Soc. 1996, 118, 7063-7068. [CrossRef]

55. Genereux, J.C.; Barton, J.K. Mechanisms for DNA charge transport. Chem. Rev. 2010, 110, $1642-1662$. [CrossRef] [PubMed]

56. Kawanishi, S.; Hiraku, Y.; Oikawa, S. Mechanism of guanine-specific DNA damage by oxidative stress and its role in carcinogenesis and aging. Mutat. Res. 2001, 488, 65-76. [CrossRef]

57. Lee-Six, H.; Øbro, N.F.; Shepherd, M.S.; Grossmann, S.; Dawson, K.; Belmonte, M.; Osborne, R.J.; Huntly, B.J.P.; Martincorena, I.; Anderson, E.; et al. Population dynamics of normal human blood inferred from somatic mutations. Nature 2018, 561, 473-478. [CrossRef]

58. Lu, T.; Pan, Y.; Kao, S.-Y.; Li, C.; Kohane, I.; Chan, J.; Yankner, B.A. Gene regulation and DNA damage in the ageing human brain. Nature 2004, 429, 883-891. [CrossRef] [PubMed]

59. Gao, Y.; Yang, W. Capture of a third $\mathrm{Mg}^{2+}$ is essential for catalyzing DNA synthesis. Science 2016, 352, 1334-1337. [CrossRef] [PubMed]

60. Freudenthal, B.D.; Beard, W.A.; Shock, D.D.; Wilson, S.H. Observing a DNA polymerase choose right from wrong. Cell 2013, 154, 157-168. [CrossRef] [PubMed]

61. Kunkel, T.A.; Bebenek, K. DNA replication fidelity. Annu. Rev. Biochem. 2000, 69, 497-529. [CrossRef]

62. Kool, E.T. Active site tightness and substrate fit in DNA replication. Annu. Rev. Biochem. 2002, 71, $191-219$. [CrossRef] [PubMed]

63. Yang, W.; Gao, Y. Translesion and repair DNA polymerases: Diverse structure and mechanism. Annu. Rev. Biochem. 2018, 87, 239-261. [CrossRef] [PubMed]

64. Kouchakdjian, M.; Bodepudi, V.; Shibutani, S.; Eisenberg, M.; Johnson, F.; Grollman, A.P.; Patel, D.J. NMR structural studies of the ionizing radiation adduct 7-hydro-8-oxodeoxyguanosine (8-oxo-7H-dG) opposite deoxyadenosine in a DNA duplex. 8-Oxo-7H-dG(syn)•dA(anti) alignment at lesion site. Biochemistry 1991, 30, 1403-1412. [CrossRef] [PubMed]

65. Oda, Y.; Uesugi, S.; Ikehara, M.; Nishimura, S.; Kawase, Y.; Ishikawa, H.; Inoue, H.; Ohtsuka, E. NMR studies of a DNA containing 8-hydroxydeoxyguanosine. Nucleic Acids Res. 1991, 19, 1407-1412. [CrossRef]

66. McAuley-Hecht, K.E.; Leonard, G.A.; Gibson, N.J.; Thomson, J.B.; Watson, W.P.; Hunter, W.N.; Brown, T. Crystal structure of a DNA duplex containing 8-hydroxydeoxyguanine-adenine base pairs. Biochemistry 1994, 33, 10266-10270. [CrossRef] [PubMed]

67. Lipscomb, L.A.; Peek, M.E.; Morningstar, M.L.; Verghis, S.M.; Miller, E.M.; Rich, A.; Essigmann, J.M.; Williams, L.D. X-ray structure of a DNA decamer containing 7,8-dihydro-8-oxoguanine. Proc. Natl Acad. Sci. USA 1995, 92, 719-723. [CrossRef]

68. Brieba, L.G.; Eichman, B.F.; Kokoska, R.J.; Doublié, S.; Kunkel, T.A.; Ellenberger, T. Structural basis for the dual coding potential of 8-oxoguanosine by a high-fidelity DNA polymerase. EMBO J. 2004, 23, 3452-3461. [CrossRef]

69. Hsu, G.W.; Ober, M.; Carell, T.; Beese, L.S. Error-prone replication of oxidatively damaged DNA by a high-fidelity DNA polymerase. Nature 2004, 431, 217-221. [CrossRef]

70. Brieba, L.G.; Kokoska, R.J.; Bebenek, K.; Kunkel, T.A.; Ellenberger, T. A lysine residue in the fingers subdomain of T7 DNA polymerase modulates the miscoding potential of 8-oxo-7,8-dihydroguanosine. Structure 2005, 13, 1653-1659. [CrossRef]

71. Burak, M.J.; Guja, K.E.; Hambardjieva, E.; Derkunt, B.; Garcia-Diaz, M. A fidelity mechanism in DNA polymerase lambda promotes error-free bypass of 8-oxo-dG. EMBO J. 2016, 35, 2045-2059. [CrossRef] 
72. Kirouac, K.N.; Ling, H. Unique active site promotes error-free replication opposite an 8-oxo-guanine lesion by human DNA polymerase iota. Proc. Natl Acad. Sci. USA 2011, 108, 3210-3215. [CrossRef] [PubMed]

73. Patra, A.; Nagy, L.D.; Zhang, Q.; Su, Y.; Müller, L.; Guengerich, F.P.; Egli, M. Kinetics, structure, and mechanism of 8-oxo-7,8-dihydro-2'-deoxyguanosine bypass by human DNA polymerase $\eta$. J. Biol. Chem. 2014, 289, 16867-16882. [CrossRef]

74. Singh, S.K.; Szulik, M.W.; Ganguly, M.; Khutsishvili, I.; Stone, M.P.; Marky, L.A.; Gold, B. Characterization of DNA with an 8-oxoguanine modification. Nucleic Acids Res. 2011, 39, 6789-6801. [CrossRef]

75. Gruber, D.R.; Toner, J.J.; Miears, H.L.; Shernyukov, A.V.; Kiryutin, A.S.; Lomzov, A.A.; Endutkin, A.V.; Grin, I.R.; Petrova, D.V.; Kupryushkin, M.S.; et al. Oxidative damage to epigenetically methylated sites affects DNA stability, dynamics, and enzymatic demethylation. Nucleic Acids Res. 2018, 46, 10827-10839. [CrossRef] [PubMed]

76. Hoppins, J.J.; Gruber, D.R.; Miears, H.L.; Kiryutin, A.S.; Kasymov, R.D.; Petrova, D.V.; Endutkin, A.V.; Popov, A.V.; Yurkovskaya, A.V.; Fedechkin, S.O.; et al. 8-Oxoguanine affects DNA backbone conformation in the EcoRI recognition site and inhibits its cleavage by the enzyme. PLoS ONE 2016, 11, e0164424. [CrossRef] [PubMed]

77. Michaels, M.L.; Tchou, J.; Grollman, A.P.; Miller, J.H. A repair system for 8-oxo-7,8-dihydrodeoxyguanine. Biochemistry 1992, 31, 10964-10968. [CrossRef]

78. Grollman, A.P.; Moriya, M. Mutagenesis by 8-oxoguanine: An enemy within. Trends Genet. 1993, 9, $246-249$. [CrossRef]

79. Tajiri, T.; Maki, H.; Sekiguchi, M. Functional cooperation of MutT, MutM and MutY proteins in preventing mutations caused by spontaneous oxidation of guanine nucleotide in Escherichia coli. Mutat. Res. 1995, 336, 257-267. [CrossRef]

80. Tchou, J.; Kasai, H.; Shibutani, S.; Chung, M.-H.; Laval, J.; Grollman, A.P.; Nishimura, S. 8-oxoguanine (8-hydroxyguanine) DNA glycosylase and its substrate specificity. Proc. Natl Acad. Sci. USA 1991, 88, 4690-4694. [CrossRef] [PubMed]

81. Tchou, J.; Bodepudi, V.; Shibutani, S.; Antoshechkin, I.; Miller, J.; Grollman, A.P.; Johnson, F. Substrate specificity of Fpg protein: Recognition and cleavage of oxidatively damaged DNA. J. Biol. Chem. 1994, 269, 15318-15324. [PubMed]

82. Karakaya, A.; Jaruga, P.; Bohr, V.A.; Grollman, A.P.; Dizdaroglu, M. Kinetics of excision of purine lesions from DNA by Escherichia coli Fpg protein. Nucleic Acids Res. 1997, 25, 474-479. [CrossRef]

83. Michaels, M.L.; Cruz, C.; Grollman, A.P.; Miller, J.H. Evidence that MutY and MutM combine to prevent mutations by an oxidatively damaged form of guanine in DNA. Proc. Natl Acad. Sci. USA 1992, 89, 7022-7025. [CrossRef] [PubMed]

84. Bulychev, N.V.; Varaprasad, C.V.; Dormán, G.; Miller, J.H.; Eisenberg, M.; Grollman, A.P.; Johnson, F. Substrate specificity of Escherichia coli MutY protein. Biochemistry 1996, 35, 13147-13156. [CrossRef] [PubMed]

85. Pavlov, Y.I.; Minnick, D.T.; Izuta, S.; Kunkel, T.A. DNA replication fidelity with 8-oxodeoxyguanosine triphosphate. Biochemistry 1994, 33, 4695-4701. [CrossRef] [PubMed]

86. Maki, H.; Sekiguchi, M. MutT protein specifically hydrolyses a potent mutagenic substrate for DNA synthesis. Nature 1992, 355, 273-275. [CrossRef]

87. Taddei, F.; Hayakawa, H.; Bouton, M.; Cirinesi, A.; Matic, I.; Sekiguchi, M.; Radman, M. Counteraction by MutT protein of transcriptional errors caused by oxidative damage. Science 1997, 278, 128-130. [CrossRef]

88. Sakumi, K.; Furuichi, M.; Tsuzuki, T.; Kakuma, T.; Kawabata, S.-i.; Maki, H.; Sekiguchi, M. Cloning and expression of cDNA for a human enzyme that hydrolyzes 8-oxo-dGTP, a mutagenic substrate for DNA synthesis. J. Biol. Chem. 1993, 268, 23524-23530.

89. Hayakawa, H.; Taketomi, A.; Sakumi, K.; Kuwano, M.; Sekiguchi, M. Generation and elimination of 8-oxo-7,8-dihydro-2'-deoxyguanosine 5'-triphosphate, a mutagenic substrate for DNA synthesis, in human cells. Biochemistry 1995, 34, 89-95. [CrossRef]

90. Slupska, M.M.; Baikalov, C.; Luther, W.M.; Chiang, J.-H.; Wei, Y.-F.; Miller, J.H. Cloning and sequencing a human homolog $(h M Y H)$ of the Escherichia coli mut $Y$ gene whose function is required for the repair of oxidative DNA damage. J. Bacteriol. 1996, 178, 3885-3892. [CrossRef] 
91. Chmiel, N.H.; Livingston, A.L.; David, S.S. Insight into the functional consequences of inherited variants of the hMYH adenine glycosylase associated with colorectal cancer: Complementation assays with hMYH variants and pre-steady-state kinetics of the corresponding mutated E. coli enzymes. J. Mol. Biol. 2003, 327, 431-443. [CrossRef]

92. Rosenquist, T.A.; Zharkov, D.O.; Grollman, A.P. Cloning and characterization of a mammalian 8-oxoguanine DNA glycosylase. Proc. Natl Acad. Sci. USA 1997, 94, 7429-7434. [CrossRef] [PubMed]

93. Radicella, J.P.; Dherin, C.; Desmaze, C.; Fox, M.S.; Boiteux, S. Cloning and characterization of hOGG1, a human homolog of the OGG1 gene of Saccharomyces cerevisiae. Proc. Natl Acad. Sci. USA 1997, 94, 8010-8015. [CrossRef] [PubMed]

94. Roldán-Arjona, T.; Wei, Y.-F.; Carter, K.C.; Klungland, A.; Anselmino, C.; Wang, R.-P.; Augustus, M.; Lindahl, T. Molecular cloning and functional expression of a human cDNA encoding the antimutator enzyme 8-hydroxyguanine-DNA glycosylase. Proc. Natl Acad. Sci. USA 1997, 94, 8016-8020. [CrossRef] [PubMed]

95. Boiteux, S.; Gellon, L.; Guibourt, N. Repair of 8-oxoguanine in Saccharomyces cerevisiae: Interplay of DNA repair and replication mechanisms. Free Radic. Biol. Med. 2002, 32, 1244-1253. [CrossRef]

96. Zharkov, D.O.; Shoham, G.; Grollman, A.P. Structural characterization of the Fpg family of DNA glycosylases. DNA Repair 2003, 2, 839-862. [CrossRef]

97. Boiteux, S.; O'Connor, T.R.; Lederer, F.; Gouyette, A.; Laval, J. Homogeneous Escherichia coli FPG protein: A DNA glycosylase which excises imidazole ring-opened purines and nicks DNA at apurinic/apyrimidinic sites. J. Biol. Chem. 1990, 265, 3916-3922.

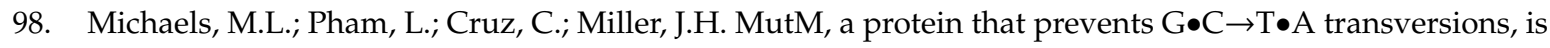
formamidopyrimidine-DNA glycosylase. Nucleic Acids Res. 1991, 19, 3629-3632. [CrossRef]

99. Gilboa, R.; Zharkov, D.O.; Golan, G.; Fernandes, A.S.; Gerchman, S.E.; Matz, E.; Kycia, J.H.; Grollman, A.P.; Shoham, G. Structure of formamidopyrimidine-DNA glycosylase covalently complexed to DNA. J. Biol. Chem. 2002, 277, 19811-19816. [CrossRef] [PubMed]

100. Sugahara, M.; Mikawa, T.; Kumasaka, T.; Yamamoto, M.; Kato, R.; Fukuyama, K.; Inoue, Y.; Kuramitsu, S. Crystal structure of a repair enzyme of oxidatively damaged DNA, MutM (Fpg), from an extreme thermophile, Thermus thermophilus HB8. EMBO J. 2000, 19, 3857-3869. [CrossRef]

101. Serre, L.; Pereira de Jésus, K.; Boiteux, S.; Zelwer, C.; Castaing, B. Crystal structure of the Lactococcus lactis formamidopyrimidine-DNA glycosylase bound to an abasic site analogue-containing DNA. EMBO J. 2002, 21, 2854-2865. [CrossRef]

102. Fromme, J.C.; Verdine, G.L. Structural insights into lesion recognition and repair by the bacterial 8-oxoguanine DNA glycosylase MutM. Nat. Struct. Biol. 2002, 9, 544-552. [CrossRef]

103. Fromme, J.C.; Verdine, G.L. DNA lesion recognition by the bacterial repair enzyme MutM. J. Biol. Chem. 2003, 278, 51543-51548. [CrossRef]

104. Qi, Y.; Spong, M.C.; Nam, K.; Banerjee, A.; Jiralerspong, S.; Karplus, M.; Verdine, G.L. Encounter and extrusion of an intrahelical lesion by a DNA repair enzyme. Nature 2009, 462, 762-766. [CrossRef]

105. Qi, Y.; Spong, M.C.; Nam, K.; Karplus, M.; Verdine, G.L. Entrapment and structure of an extrahelical guanine attempting to enter the active site of a bacterial DNA glycosylase, MutM. J. Biol. Chem. 2010, 285, 1468-1478. [CrossRef] [PubMed]

106. Coste, F.; Ober, M.; Carell, T.; Boiteux, S.; Zelwer, C.; Castaing, B. Structural basis for the recognition of the FapydG lesion (2,6-diamino-4-hydroxy-5-formamidopyrimidine) by formamidopyrimidine-DNA glycosylase. J. Biol. Chem. 2004, 279, 44074-44083. [CrossRef]

107. Coste, F.; Ober, M.; Le Bihan, Y.-V.; Izquierdo, M.A.; Hervouet, N.; Mueller, H.; Carell, T.; Castaing, B. Bacterial base excision repair enzyme Fpg recognizes bulky $N^{7}$-substituted-FapydG lesion via unproductive binding mode. Chem. Biol. 2008, 15, 706-717. [CrossRef] [PubMed]

108. Popov, A.V.; Endutkin, A.V.; Vorobjev, Y.N.; Zharkov, D.O. Molecular dynamics simulation of the opposite-base preference and interactions in the active site of formamidopyrimidine-DNA glycosylase. BMC Struct. Biol. 2017, 17, 5. [CrossRef] [PubMed]

109. Sadeghian, K.; Flaig, D.; Blank, I.D.; Schneider, S.; Strasser, R.; Stathis, D.; Winnacker, M.; Carell, T.; Ochsenfeld, C. Ribose-protonated DNA base excision repair: A combined theoretical and experimental study. Angew. Chem. Int. Ed. 2014, 53, 10044-10048. [CrossRef]

110. Bruner, S.D.; Norman, D.P.G.; Verdine, G.L. Structural basis for recognition and repair of the endogenous mutagen 8-oxoguanine in DNA. Nature 2000, 403, 859-866. [CrossRef] [PubMed] 
111. Zaika, E.I.; Perlow, R.A.; Matz, E.; Broyde, S.; Gilboa, R.; Grollman, A.P.; Zharkov, D.O. Substrate discrimination by formamidopyrimidine-DNA glycosylase: A mutational analysis. J. Biol. Chem. 2004, 279, 4849-4861. [CrossRef]

112. Perlow-Poehnelt, R.A.; Zharkov, D.O.; Grollman, A.P.; Broyde, S. Substrate discrimination by formamidopyrimidine-DNA glycosylase: Distinguishing interactions within the active site. Biochemistry 2004, 43, 16092-16105. [CrossRef]

113. Song, K.; Hornak, V.; de los Santos, C.; Grollman, A.P.; Simmerling, C. Computational analysis of the mode of binding of 8-oxoguanine to formamidopyrimidine-DNA glycosylase. Biochemistry 2006, 45, 10886-10894. [CrossRef] [PubMed]

114. Song, K.; Kelso, C.; de los Santos, C.; Grollman, A.P.; Simmerling, C. Molecular simulations reveal a common binding mode for glycosylase binding of oxidatively damaged DNA lesions. J. Am. Chem. Soc. 2007, 129, 14536-14537. [CrossRef]

115. Kuznetsov, N.A.; Koval, V.V.; Zharkov, D.O.; Vorobjev, Y.N.; Nevinsky, G.A.; Douglas, K.T.; Fedorova, O.S. Pre-steady-state kinetic study of substrate specificity of Escherichia coli formamidopyrimidine-DNA glycosylase. Biochemistry 2007, 46, 424-435. [CrossRef] [PubMed]

116. Dherin, C.; Radicella, J.P.; Dizdaroglu, M.; Boiteux, S. Excision of oxidatively damaged DNA bases by the human $\alpha$-hOgg1 protein and the polymorphic $\alpha$-hOgg1(Ser326Cys) protein which is frequently found in human populations. Nucleic Acids Res. 1999, 27, 4001-4007. [CrossRef]

117. Auffret van der Kemp, P.; Thomas, D.; Barbey, R.; de Oliveira, R.; Boiteux, S. Cloning and expression in Escherichia coli of the OGG1 gene of Saccharomyces cerevisiae, which codes for a DNA glycosylase that excises 7,8-dihydro-8-oxoguanine and 2,6-diamino-4-hydroxy-5-N-methylformamidopyrimidine. Proc. Natl Acad. Sci. USA 1996, 93, 5197-5202. [CrossRef]

118. Nash, H.M.; Bruner, S.D.; Schärer, O.D.; Kawate, T.; Addona, T.A.; Spooner, E.; Lane, W.S.; Verdine, G.L. Cloning of a yeast 8-oxoguanine DNA glycosylase reveals the existence of a base-excision DNA-repair protein superfamily. Curr. Biol. 1996, 6, 968-980. [CrossRef]

119. Nash, H.M.; Lu, R.; Lane, W.S.; Verdine, G.L. The critical active-site amine of the human 8-oxoguanine DNA glycosylase, hOgg1: Direct identification, ablation and chemical reconstitution. Chem. Biol. 1997, 4, 693-702. [CrossRef]

120. Banerjee, A.; Yang, W.; Karplus, M.; Verdine, G.L. Structure of a repair enzyme interrogating undamaged DNA elucidates recognition of damaged DNA. Nature 2005, 434, 612-618. [CrossRef] [PubMed]

121. Radom, C.T.; Banerjee, A.; Verdine, G.L. Structural characterization of human 8-oxoguanine DNA glycosylase variants bearing active site mutations. J. Biol. Chem. 2007, 282, 9182-9194. [CrossRef]

122. Lukina, M.V.; Popov, A.V.; Koval, V.V.; Vorobjev, Y.N.; Fedorova, O.S.; Zharkov, D.O. DNA damage processing by human 8-oxoguanine-DNA glycosylase mutants with the occluded active site. J. Biol. Chem. 2013, 288, 28936-28947. [CrossRef] [PubMed]

123. Fromme, J.C.; Bruner, S.D.; Yang, W.; Karplus, M.; Verdine, G.L. Product-assisted catalysis in base-excision DNA repair. Nat. Struct. Biol. 2003, 10, 204-211. [CrossRef]

124. Faucher, F.; Robey-Bond, S.M.; Wallace, S.S.; Doublié, S. Structural characterization of Clostridium acetobutylicum 8-oxoguanine DNA glycosylase in its apo form and in complex with 8-oxodeoxyguanosine. J. Mol. Biol. 2009, 387, 669-679. [CrossRef] [PubMed]

125. Faucher, F.; Wallace, S.S.; Doublié, S. Structural basis for the lack of opposite base specificity of Clostridium acetobutylicum 8-oxoguanine DNA glycosylase. DNA Repair 2009, 8, 1283-1289. [CrossRef] [PubMed]

126. Yu, H.; Yang, M.; Zhang, X.-e.; Bi, L.; Jiang, T. Crystal structures of MBOgg1 in complex with two abasic DNA ligands. J. Struct. Biol. 2013, 181, 252-263. [CrossRef] [PubMed]

127. Banerjee, A.; Santos, W.L.; Verdine, G.L. Structure of a DNA glycosylase searching for lesions. Science 2006, 311, 1153-1157. [CrossRef]

128. Nam, K.; Verdine, G.L.; Karplus, M. Analysis of an anomalous mutant of MutM DNA glycosylase leads to new insights into the catalytic mechanism. J. Am. Chem. Soc. 2009, 131, 18208-18209. [CrossRef]

129. Qi, Y.; Nam, K.; Spong, M.C.; Banerjee, A.; Sung, R.-J.; Zhang, M.; Karplus, M.; Verdine, G.L. Strandwise translocation of a DNA glycosylase on undamaged DNA. Proc. Natl Acad. Sci. USA 2012, 109, 1086-1091. [CrossRef] 
130. Sung, R.-J.; Zhang, M.; Qi, Y.; Verdine, G.L. Sequence-dependent structural variation in DNA undergoing intrahelical inspection by the DNA glycosylase MutM. J. Biol. Chem. 2012, 287, 18044-18054. [CrossRef] [PubMed]

131. Sung, R.-J.; Zhang, M.; Qi, Y.; Verdine, G.L. Structural and biochemical analysis of DNA helix invasion by the bacterial 8-oxoguanine DNA glycosylase MutM. J. Biol. Chem. 2013, 288, 10012-10023. [CrossRef] [PubMed]

132. Norman, D.P.G.; Bruner, S.D.; Verdine, G.L. Coupling of substrate recognition and catalysis by a human base-excision DNA repair protein. J. Am. Chem. Soc. 2001, 123, 359-360. [CrossRef] [PubMed]

133. Bjørås, M.; Seeberg, E.; Luna, L.; Pearl, L.H.; Barrett, T.E. Reciprocal “flipping” underlies substrate recognition and catalytic activation by the human 8-oxo-guanine DNA glycosylase. J. Mol. Biol. 2002, 317, 171-177. [CrossRef] [PubMed]

134. Norman, D.P.G.; Chung, S.J.; Verdine, G.L. Structural and biochemical exploration of a critical amino acid in human 8-oxoguanine glycosylase. Biochemistry 2003, 42, 1564-1572. [CrossRef] [PubMed]

135. Chung, S.J.; Verdine, G.L. Structures of end products resulting from lesion processing by a DNA glycosylase/lyase. Chem. Biol. 2004, 11, 1643-1649. [CrossRef] [PubMed]

136. Banerjee, A.; Verdine, G.L. A nucleobase lesion remodels the interaction of its normal neighbor in a DNA glycosylase complex. Proc. Natl Acad. Sci. USA 2006, 103, 15020-15025. [CrossRef] [PubMed]

137. Lee, S.; Radom, C.T.; Verdine, G.L. Trapping and structural elucidation of a very advanced intermediate in the lesion-extrusion pathway of hOGG1. J. Am. Chem. Soc. 2008, 130, 7784-7785. [CrossRef]

138. Crenshaw, C.M.; Nam, K.; Oo, K.; Kutchukian, P.S.; Bowman, B.R.; Karplus, M.; Verdine, G.L. Enforced presentation of an extrahelical guanine to the lesion recognition pocket of human 8-oxoguanine glycosylase, hOGG1. J. Biol. Chem. 2012, 287, 24916-24928. [CrossRef]

139. Bergonzo, C.; Campbell, A.J.; de los Santos, C.; Grollman, A.P.; Simmerling, C. Energetic preference of 8-oxoG eversion pathways in a DNA glycosylase. J. Am. Chem. Soc. 2011, 133, 14504-14506. [CrossRef]

140. Kuznetsov, N.A.; Bergonzo, C.; Campbell, A.J.; Li, H.; Mechetin, G.V.; de los Santos, C.; Grollman, A.P.; Fedorova, O.S.; Zharkov, D.O.; Simmerling, C. Active destabilization of base pairs by a DNA glycosylase wedge initiates damage recognition. Nucleic Acids Res. 2015, 43, 272-281. [CrossRef]

141. Li, H.; Endutkin, A.V.; Bergonzo, C.; Campbell, A.J.; de los Santos, C.; Grollman, A.; Zharkov, D.O.; Simmerling, C. A dynamic checkpoint in oxidative lesion discrimination by formamidopyrimidine-DNA glycosylase. Nucleic Acids Res. 2016, 44, 683-694. [CrossRef]

142. Li, H.; Endutkin, A.V.; Bergonzo, C.; Fu, L.; Grollman, A.P.; Zharkov, D.O.; Simmerling, C. DNA deformation-coupled recognition of 8-oxoguanine: Conformational kinetic gating in human DNA glycosylase. J. Am. Chem. Soc. 2017, 139, 2682-2692. [CrossRef] [PubMed]

143. Koval, V.V.; Kuznetsov, N.A.; Zharkov, D.O.; Ishchenko, A.A.; Douglas, K.T.; Nevinsky, G.A.; Fedorova, O.S. Pre-steady-state kinetics shows differences in processing of various DNA lesions by Escherichia coli formamidopyrimidine-DNA glycosylase. Nucleic Acids Res. 2004, 32, 926-935. [CrossRef] [PubMed]

144. Kuznetsov, N.A.; Koval, V.V.; Zharkov, D.O.; Nevinsky, G.A.; Douglas, K.T.; Fedorova, O.S. Kinetics of substrate recognition and cleavage by human 8-oxoguanine-DNA glycosylase. Nucleic Acids Res. 2005, 33, 3919-3931. [CrossRef] [PubMed]

145. Kuznetsov, N.A.; Koval, V.V.; Nevinsky, G.A.; Douglas, K.T.; Zharkov, D.O.; Fedorova, O.S. Kinetic conformational analysis of human 8-oxoguanine-DNA glycosylase. J. Biol. Chem. 2007, 282, 1029-1038. [CrossRef]

146. Kuznetsov, N.A.; Zharkov, D.O.; Koval, V.V.; Buckle, M.; Fedorova, O.S. Reversible chemical step and rate-limiting enzyme regeneration in the reaction catalyzed by formamidopyrimidine-DNA-glycosylase. Biochemistry 2009, 48, 11335-11343. [CrossRef] [PubMed]

147. Kuznetsov, N.A.; Vorobjev, Y.N.; Krasnoperov, L.N.; Fedorova, O.S. Thermodynamics of the multi-stage DNA lesion recognition and repair by formamidopyrimidine-DNA glycosylase using pyrrolocytosine fluorescence-stopped-flow pre-steady-state kinetics. Nucleic Acids Res. 2012, 40, 7384-7392. [CrossRef]

148. Kuznetsov, N.A.; Kuznetsova, A.A.; Vorobjev, Y.N.; Krasnoperov, L.N.; Fedorova, O.S. Thermodynamics of the DNA damage repair steps of human 8-oxoguanine DNA glycosylase. PLoS ONE 2014, 9, e98495. [CrossRef]

149. Kuznetsova, A.A.; Kuznetsov, N.A.; Ishchenko, A.A.; Saparbaev, M.K.; Fedorova, O.S. Step-by-step mechanism of DNA damage recognition by human 8-oxoguanine DNA glycosylase. Biochim. Biophys. Acta 2014, 1840, 387-395. [CrossRef] 
150. Lukina, M.V.; Koval, V.V.; Lomzov, A.A.; Zharkov, D.O.; Fedorova, O.S. Global DNA dynamics of 8-oxoguanine repair by human OGG1 revealed by stopped-flow kinetics and molecular dynamic simulation. Mol. Biosyst. 2017, 13, 1954-1966. [CrossRef] [PubMed]

151. Boon, E.M.; Pope, M.A.; Williams, S.D.; David, S.S.; Barton, J.K. DNA-mediated charge transport as a probe of MutY/DNA interaction. Biochemistry 2002, 41, 8464-8470. [CrossRef]

152. Boon, E.M.; Livingston, A.L.; Chmiel, N.H.; David, S.S.; Barton, J.K. DNA-mediated charge transport for DNA repair. Proc. Natl Acad. Sci. USA 2003, 100, 12543-12547. [CrossRef] [PubMed]

153. Boal, A.K.; Yavin, E.; Lukianova, O.A.; O'Shea, V.L.; David, S.S.; Barton, J.K. DNA-bound redox activity of DNA repair glycosylases containing [4Fe-4S] clusters. Biochemistry 2005, 44, 8397-8407. [CrossRef] [PubMed]

154. Yavin, E.; Boal, A.K.; Stemp, E.D.A.; Boon, E.M.; Livingston, A.L.; O'Shea, V.L.; David, S.S.; Barton, J.K. Protein-DNA charge transport: Redox activation of a DNA repair protein by guanine radical. Proc. Natl Acad. Sci. USA 2005, 102, 3546-3551. [CrossRef] [PubMed]

155. Yavin, E.; Stemp, E.D.A.; O'Shea, V.L.; David, S.S.; Barton, J.K. Electron trap for DNA-bound repair enzymes: A strategy for DNA-mediated signaling. Proc. Natl Acad. Sci. USA 2006, 103, 3610-3614. [CrossRef] [PubMed]

156. Bessman, M.J.; Frick, D.N.; O’Handley, S.F. The MutT proteins or "nudix" hydrolases, a family of versatile, widely distributed, "housecleaning" enzymes. J. Biol. Chem. 1996, 271, 25059-25062. [CrossRef]

157. Mildvan, A.S.; Xia, Z.; Azurmendi, H.F.; Saraswat, V.; Legler, P.M.; Massiah, M.A.; Gabelli, S.B.; Bianchet, M.A.; Kang, L.-W.; Amzel, L.M. Structures and mechanisms of Nudix hydrolases. Arch. Biochem. Biophys. 2005, 433, 129-143. [CrossRef] [PubMed]

158. Nakamura, T.; Meshitsuka, S.; Kitagawa, S.; Abe, N.; Yamada, J.; Ishino, T.; Nakano, H.; Tsuzuki, T.; Doi, T.; Kobayashi, Y.; et al. Structural and dynamic features of the MutT protein in the recognition of nucleotides with the mutagenic 8-oxoguanine base. J. Biol. Chem. 2010, 285, 444-452. [CrossRef]

159. Massiah, M.A.; Saraswat, V.; Azurmendi, H.F.; Mildvan, A.S. Solution structure and NH exchange studies of the MutT pyrophosphohydrolase complexed with $\mathrm{Mg}^{2+}$ and 8-oxo-dGMP, a tightly bound product. Biochemistry 2003, 42, 10140-10154. [CrossRef]

160. Lin, J.; Abeygunawardana, C.; Frick, D.N.; Bessman, M.J.; Mildvan, A.S. Solution structure of the quaternary MutT-M ${ }^{2+}-\mathrm{AMPCPP}-\mathrm{M}^{2+}$ complex and mechanism of its pyrophosphohydrolase action. Biochemistry 1997, 36, 1199-1211. [CrossRef]

161. Higuchi, M.; Fujii, J.; Yonetani, Y.; Kitao, A.; Go, N. Enhanced resolution of molecular recognition to distinguish structurally similar molecules by different conformational responses of a protein upon ligand binding. J. Struct. Biol. 2011, 173, 20-28. [CrossRef]

162. Ito, R.; Hayakawa, H.; Sekiguchi, M.; Ishibashi, T. Multiple enzyme activities of Escherichia coli MutT protein for sanitization of DNA and RNA precursor pools. Biochemistry 2005, 44, 6670-6674. [CrossRef]

163. Waz, S.; Nakamura, T.; Hirata, K.; Koga-Ogawa, Y.; Chirifu, M.; Arimori, T.; Tamada, T.; Ikemizu, S.; Nakabeppu, Y.; Yamagata, Y. Structural and kinetic studies of the human Nudix hydrolase MTH1 reveal the mechanism for its broad substrate specificity. J. Biol. Chem. 2017, 292, 2785-2794. [CrossRef]

164. Fromme, J.C.; Banerjee, A.; Huang, S.J.; Verdine, G.L. Structural basis for removal of adenine mispaired with 8-oxoguanine by MutY adenine DNA glycosylase. Nature 2004, 427, 652-656. [CrossRef] [PubMed]

165. Svensson, L.M.; Jemth, A.-S.; Desroses, M.; Loseva, O.; Helleday, T.; Högbom, M.; Stenmark, P. Crystal structure of human MTH1 and the 8-oxo-dGMP product complex. FEBS Lett. 2011, 585, 2617-2621. [CrossRef] [PubMed]

166. Nissink, J.W.M.; Bista, M.; Breed, J.; Carter, N.; Embrey, K.; Read, J.; Winter-Holt, J.J. MTH1 substrate recognition-An example of specific promiscuity. PLoS ONE 2016, 11, e0151154. [CrossRef] [PubMed]

167. Narwal, M.; Jemth, A.-S.; Gustafsson, R.; Almlöf, I.; Warpman Berglund, U.; Helleday, T.; Stenmark, P. Crystal structures and inhibitor interactions of mouse and dog MTH1 reveal species-specific differences in affinity. Biochemistry 2018, 57, 593-603. [CrossRef]

168. Jemth, A.-S.; Gustafsson, R.; Bräutigam, L.; Henriksson, L.; Vallin, K.S.A.; Sarno, A.; Almlöf, I.; Homan, E.; Rasti, A.; Warpman Berglund, U.; et al. MutT homologue 1 (MTH1) catalyzes the hydrolysis of mutagenic O6-methyl-dGTP. Nucleic Acids Res. 2018, 46, 10888-10904. [CrossRef]

169. Fujikawa, K.; Kamiya, H.; Yakushiji, H.; Nakabeppu, Y.; Kasai, H. Human MTH1 protein hydrolyzes the oxidized ribonucleotide, 2-hydroxy-ATP. Nucleic Acids Res. 2001, 29, 449-454. [CrossRef] [PubMed] 
170. Fujikawa, K.; Kamiya, H.; Yakushiji, H.; Fujii, Y.; Nakabeppu, Y.; Kasai, H. The oxidized forms of dATP are substrates for the human MutT homologue, the hMTH1 protein. J. Biol. Chem. 1999, 274, 18201-18205. [CrossRef] [PubMed]

171. Fujikawa, K.; Yakushiji, H.; Nakabeppu, Y.; Suzuki, T.; Masuda, M.; Ohshima, H.; Kasai, H. 8-Chloro-dGTP, a hypochlorous acid-modified nucleotide, is hydrolyzed by hMTH1, the human MutT homolog. FEBS Lett. 2002, 512, 149-151. [CrossRef]

172. Nghiem, Y.; Cabrera, M.; Cupples, C.G.; Miller, J.H. The mutY gene: A mutator locus in Escherichia coli that generates $\mathrm{G} \bullet \mathrm{C} \rightarrow \mathrm{T} \bullet$ A transversions. Proc. Natl Acad. Sci. USA 1988, 85, 2709-2713. [CrossRef] [PubMed]

173. Au, K.G.; Cabrera, M.; Miller, J.H.; Modrich, P. Escherichia coli mutY gene product is required for specific A-G $\rightarrow$ C $\bullet$ G mismatch correction. Proc. Natl Acad. Sci. USA 1988, 85, 9163-9166. [CrossRef]

174. Radicella, J.P.; Clark, E.A.; Fox, M.S. Some mismatch repair activities in Escherichia coli. Proc. Natl Acad. Sci. USA 1988, 85, 9674-9678. [CrossRef] [PubMed]

175. Au, K.G.; Clark, S.; Miller, J.H.; Modrich, P. Escherichia coli mutY gene encodes an adenine glycosylase active on G-A mispairs. Proc. Natl Acad. Sci. USA 1989, 86, 8877-8881. [CrossRef]

176. Gogos, A.; Cillo, J.; Clarke, N.D.; Lu, A.-L. Specific recognition of A/G and A/7,8-dihydro-8-oxoguanine (8-oxoG) mismatches by Escherichia coli MutY: Removal of the C-terminal domain preferentially affects A/8-oxoG recognition. Biochemistry 1996, 35, 16665-16671. [CrossRef] [PubMed]

177. Manuel, R.C.; Czerwinski, E.W.; Lloyd, R.S. Identification of the structural and functional domains of MutY, an Escherichia coli DNA mismatch repair enzyme. J. Biol. Chem. 1996, 271, 16218-16226. [CrossRef]

178. Noll, D.M.; Gogos, A.; Granek, J.A.; Clarke, N.D. The C-terminal domain of the adenine-DNA glycosylase MutY confers specificity for 8-oxoguanine•adenine mispairs and may have evolved from MutT, an 8-oxo-dGTPase. Biochemistry 1999, 38, 6374-6379. [CrossRef]

179. Volk, D.E.; House, P.G.; Thiviyanathan, V.; Luxon, B.A.; Zhang, S.; Lloyd, R.S.; Gorenstein, D.G. Structural similarities between MutT and the C-terminal domain of MutY. Biochemistry 2000, 39, 7331-7336. [CrossRef]

180. Lee, S.; Verdine, G.L. Atomic substitution reveals the structural basis for substrate adenine recognition and removal by adenine DNA glycosylase. Proc. Natl Acad. Sci. USA 2009, 106, 18497-18502. [CrossRef]

181. Bernards, A.S.; Miller, J.K.; Bao, K.K.; Wong, I. Flipping duplex DNA inside out: A double base-flipping reaction mechanism by Escherichia coli MutY adenine glycosylase. J. Biol. Chem. 2002, 277, 20960-20964. [CrossRef]

182. Hickerson, R.P.; Chepanoske, C.L.; Williams, S.D.; David, S.S.; Burrows, C.J. Mechanism-based DNA-protein cross-linking of MutY via oxidation of 8-oxoguanosine. J. Am. Chem. Soc. 1999, 121, 9901-9902. [CrossRef]

183. Ito, R.; Sekiguchi, M.; Setoyama, D.; Nakatsu, Y.; Yamagata, Y.; Hayakawa, H. Cleavage of oxidized guanine nucleotide and ADP sugar by human NUDT5 protein. J. Biochem. 2011, 149, 731-738. [CrossRef] [PubMed]

184. Arimori, T.; Tamaoki, H.; Nakamura, T.; Kamiya, H.; Ikemizu, S.; Takagi, Y.; Ishibashi, T.; Harashima, H.; Sekiguchi, M.; Yamagata, Y. Diverse substrate recognition and hydrolysis mechanisms of human NUDT5. Nucleic Acids Res. 2011, 39, 8972-8983. [CrossRef]

185. Dos Vultos, T.; Blázquez, J.; Rauzier, J.; Matic, I.; Gicquel, B. Identification of Nudix hydrolase family members with an antimutator role in Mycobacterium tuberculosis and Mycobacterium smegmatis. J. Bacteriol. 2006, 188, 3159-3161. [CrossRef]

186. Patil, A.G.G.; Sang, P.B.; Govindan, A.; Varshney, U. Mycobacterium tuberculosis MutT1 (Rv2985) and ADPRase (Rv1700) proteins constitute a two-stage mechanism of 8-oxo-dGTP and 8-oxo-GTP detoxification and adenosine to cytidine mutation avoidance. J. Biol. Chem. 2013, 288, 11252-11262. [CrossRef]

187. Arczewska, K.D.; Baumeier, C.; Kassahun, H.; SenGupta, T.; Bjørås, M.; Kuśmierek, J.T.; Nilsen, H. Caenorhabditis elegans NDX-4 is a MutT-type enzyme that contributes to genomic stability. DNA Repair 2011, 10, 176-187. [CrossRef]

188. Xu, W.; Jones, C.R.; Dunn, C.A.; Bessman, M.J. Gene ytkD of Bacillus subtilis encodes an atypical nucleoside triphosphatase member of the Nudix hydrolase superfamily. J. Bacteriol. 2004, 186, 8380-8384. [CrossRef]

189. Winward, L.; Whitfield, W.G.F.; McLennan, A.G.; Safrany, S.T. Oxidation of the diphosphoinositol polyphosphate phosphohydrolase-like Nudix hydrolase Aps from Drosophila melanogaster induces thermolability-A possible regulatory switch? Int. J. Biochem. Cell Biol. 2010, 42, 1174-1181. [CrossRef] [PubMed] 
190. Nunoshiba, T.; Ishida, R.; Sasaki, M.; Iwai, S.; Nakabeppu, Y.; Yamamoto, K. A novel Nudix hydrolase for oxidized purine nucleoside triphosphates encoded by ORFYLR151c (PCD1 gene) in Saccharomyces cerevisiae. Nucleic Acids Res. 2004, 32, 5339-5348. [CrossRef] [PubMed]

191. Cai, J.-P.; Ishibashi, T.; Takagi, Y.; Hayakawa, H.; Sekiguchi, M. Mouse MTH2 protein which prevents mutations caused by 8-oxoguanine nucleotides. Biochem. Biophys. Res. Commun. 2003, 305, 1073-1077. [CrossRef]

192. Carter, M.; Jemth, A.-S.; Hagenkort, A.; Page, B.D.G.; Gustafsson, R.; Griese, J.J.; Gad, H.; Valerie, N.C.K.; Desroses, M.; Boström, J.; et al. Crystal structure, biochemical and cellular activities demonstrate separate functions of MTH1 and MTH2. Nat. Commun. 2015, 6, 7871. [CrossRef]

193. Takagi, Y.; Setoyama, D.; Ito, R.; Kamiya, H.; Yamagata, Y.; Sekiguchi, M. Human MTH3 (NUDT18) protein hydrolyzes oxidized forms of guanosine and deoxyguanosine diphosphates: Comparison with MTH1 and MTH2. J. Biol. Chem. 2012, 287, 21541-21549. [CrossRef] [PubMed]

194. Arif, S.M.; Patil, A.G.; Varshney, U.; Vijayan, M. Biochemical and structural studies of Mycobacterium smegmatis MutT1, a sanitization enzyme with unusual modes of association. Acta Crystallogr. D Struct. Biol. 2017, 73, 349-364. [CrossRef]

195. Ray, S.; Menezes, M.R.; Senejani, A.; Sweasy, J.B. Cellular roles of DNA polymerase beta. Yale J. Biol. Med. 2013, 86, 463-469.

196. Belousova, E.A.; Lavrik, O.I. DNA polymerases $\beta$ and $\lambda$ and their roles in cell. DNA Repair 2015, 29, 112-126. [CrossRef] [PubMed]

197. Miller, H.; Prasad, R.; Wilson, S.H.; Johnson, F.; Grollman, A.P. 8-OxodGTP incorporation by DNA polymerase $\beta$ is modified by active-site residue Asn279. Biochemistry 2000, 39, 1029-1033. [CrossRef]

198. Brown, J.A.; Duym, W.W.; Fowler, J.D.; Suo, Z. Single-turnover kinetic analysis of the mutagenic potential of 8-oxo-7,8-dihydro-2'-deoxyguanosine during gap-filling synthesis catalyzed by human DNA polymerases $\lambda$ and $\beta$. J. Mol. Biol. 2007, 367, 1258-1269. [CrossRef] [PubMed]

199. Freudenthal, B.D.; Beard, W.A.; Wilson, S.H. DNA polymerase minor groove interactions modulate mutagenic bypass of a templating 8-oxoguanine lesion. Nucleic Acids Res. 2013, 41, 1848-1858. [CrossRef]

200. Reed, A.J.; Suo, Z. Time-dependent extension from an 8-oxoguanine lesion by human DNA polymerase beta. J. Am. Chem. Soc. 2017, 139, 9684-9690. [CrossRef] [PubMed]

201. Hashimoto, K.; Tominaga, Y.; Nakabeppu, Y.; Moriya, M. Futile short-patch DNA base excision repair of adenine:8-oxoguanine mispair. Nucleic Acids Res. 2004, 32, 5928-5934. [CrossRef]

202. Picher, A.J.; Blanco, L. Human DNA polymerase lambda is a proficient extender of primer ends paired to 7,8-dihydro-8-oxoguanine. DNA Repair 2007, 6, 1749-1756. [CrossRef]

203. Zhang, Y.; Yuan, F.; Wu, X.; Taylor, J.-S.; Wang, Z. Response of human DNA polymerase ı to DNA lesions. Nucleic Acids Res. 2001, 29, 928-935. [CrossRef]

204. Vaisman, A.; Woodgate, R. Unique misinsertion specificity of polı may decrease the mutagenic potential of deaminated cytosines. EMBO J. 2001, 20, 6520-6529. [CrossRef]

205. Kirouac, K.N.; Ling, H. Structural basis of error-prone replication and stalling at a thymine base by human DNA polymerase ı. EMBO J. 2009, 28, 1644-1654. [CrossRef]

206. Johnson, R.E.; Haracska, L.; Prakash, L.; Prakash, S. Role of Hoogsteen edge hydrogen bonding at template purines in nucleotide incorporation by human DNA polymerase ı. Mol. Cell. Biol. 2006, 26, 6435-6441. [CrossRef] [PubMed]

207. Haracska, L.; Yu, S.-L.; Johnson, R.E.; Prakash, L.; Prakash, S. Efficient and accurate replication in the presence of 7,8-dihydro-8-oxoguanine by DNA polymerase $\eta$. Nat. Genet. 2000, 25, 458-461. [CrossRef] [PubMed]

208. Zhang, Y.; Yuan, F.; Wu, X.; Rechkoblit, O.; Taylor, J.-S.; Geacintov, N.E.; Wang, Z. Error-prone lesion bypass by human DNA polymerase $\eta$. Nucleic Acids Res. 2000, 28, 4717-4724. [CrossRef]

209. McCulloch, S.D.; Kokoska, R.J.; Garg, P.; Burgers, P.M.; Kunkel, T.A. The efficiency and fidelity of 8-oxo-guanine bypass by DNA polymerases $\delta$ and $\eta$. Nucleic Acids Res. 2009, 37, 2830-2840. [CrossRef] [PubMed]

210. Irimia, A.; Eoff, R.L.; Guengerich, F.P.; Egli, M. Structural and functional elucidation of the mechanism promoting error-prone synthesis by human DNA polymerase $\mathrm{K}$ opposite the 7,8-dihydro-8-oxo-2'-deoxyguanosine adduct. J. Biol. Chem. 2009, 284, 22467-22480. [CrossRef] 
211. Zhang, Y.; Yuan, F.; Wu, X.; Wang, M.; Rechkoblit, O.; Taylor, J.-S.; Geacintov, N.E.; Wang, Z. Error-free and error-prone lesion bypass by human DNA polymerase $\mathrm{k}$ in vitro. Nucleic Acids Res. 2000, 28, 4138-4146. [CrossRef]

212. Jałoszyński, P.; Ohashi, E.; Ohmori, H.; Nishimura, S. Error-prone and inefficient replication across 8-hydroxyguanine (8-oxoguanine) in human and mouse ras gene fragments by DNA polymerase k. Genes Cells 2005, 10, 543-550. [CrossRef]

213. Krahn, J.M.; Beard, W.A.; Miller, H.; Grollman, A.P.; Wilson, S.H. Structure of DNA polymerase $\beta$ with the mutagenic DNA lesion 8-oxodeoxyguanine reveals structural insights into its coding potential. Structure 2003, 11, 121-127. [CrossRef]

214. Batra, V.K.; Shock, D.D.; Beard, W.A.; McKenna, C.E.; Wilson, S.H. Binary complex crystal structure of DNA polymerase $\beta$ reveals multiple conformations of the templating 8-oxoguanine lesion. Proc. Natl Acad. Sci. USA 2012, 109, 113-118. [CrossRef] [PubMed]

215. Freudenthal, B.D.; Beard, W.A.; Wilson, S.H. Structures of dNTP intermediate states during DNA polymerase active site assembly. Structure 2012, 20, 1829-1837. [CrossRef] [PubMed]

216. Vyas, R.; Reed, A.J.; Tokarsky, E.J.; Suo, Z. Viewing human DNA polymerase $\beta$ faithfully and unfaithfully bypass an oxidative lesion by time-dependent crystallography. J. Am. Chem. Soc. 2015, 137, 5225-5230. [CrossRef]

217. Wang, Y.; Reddy, S.; Beard, W.A.; Wilson, S.H.; Schlick, T. Differing conformational pathways before and after chemistry for insertion of dATP versus dCTP opposite 8-oxoG in DNA polymerase $\beta$. Biophys. J. 2007, 92, 3063-3070. [CrossRef]

218. Wang, Y.; Schlick, T. Distinct energetics and closing pathways for DNA polymerase $\beta$ with 8-oxoG template and different incoming nucleotides. BMC Struct. Biol. 2007, 7, 7. [CrossRef] [PubMed]

219. Braithwaite, E.K.; Kedar, P.S.; Lan, L.; Polosina, Y.Y.; Asagoshi, K.; Poltoratsky, V.P.; Horton, J.K.; Miller, H.; Teebor, G.W.; Yasui, A.; et al. DNA polymerase $\lambda$ protects mouse fibroblasts against oxidative DNA damage and is recruited to sites of DNA damage/repair. J. Biol. Chem. 2005, 280, 31641-31647. [CrossRef]

220. Tano, K.; Nakamura, J.; Asagoshi, K.; Arakawa, H.; Sonoda, E.; Braithwaite, E.K.; Prasad, R.; Buerstedde, J.-M.; Takeda, S.; Watanabe, M.; et al. Interplay between DNA polymerases $\beta$ and $\lambda$ in repair of oxidation DNA damage in chicken DT40 cells. DNA Repair 2007, 6, 869-875. [CrossRef]

221. van Loon, B.; Hübscher, U. An 8-oxo-guanine repair pathway coordinated by MUTYH glycosylase and DNA polymerase $\lambda$. Proc. Natl Acad. Sci. USA 2009, 106, 18201-18206. [CrossRef]

222. Crespan, E.; Maga, G.; Hübscher, U. A new proofreading mechanism for lesion bypass by DNA polymerase- $\lambda$. EMBO Rep. 2011, 13, 68-74. [CrossRef]

223. Kamiya, H.; Kurokawa, M.; Makino, T.; Kobayashi, M.; Matsuoka, I. Induction of action-at-a-distance mutagenesis by 8-oxo-7,8-dihydroguanine in DNA pol $\lambda$-knockdown cells. Genes Environ. 2015, 37, 10. [CrossRef] [PubMed]

224. Lee, D.-H.; Pfeifer, G.P. Translesion synthesis of 7,8-dihydro-8-oxo-2'-deoxyguanosine by DNA polymerase eta in vivo. Mutat. Res. 2008, 641, 19-26. [CrossRef]

225. Kamiya, H.; Yamaguchi, A.; Suzuki, T.; Harashima, H. Roles of specialized DNA polymerases in mutagenesis by 8-hydroxyguanine in human cells. Mutat. Res. 2010, 686, 90-95. [CrossRef] [PubMed]

226. Petta, T.B.; Nakajima, S.; Zlatanou, A.; Despras, E.; Couve-Privat, S.; Ishchenko, A.; Sarasin, A.; Yasui, A.; Kannouche, P. Human DNA polymerase iota protects cells against oxidative stress. EMBO J. 2008, 27, 2883-2895. [CrossRef] [PubMed]

227. Kamiya, H.; Kurokawa, M. Mutagenic bypass of 8-oxo-7,8-dihydroguanine (8-hydroxyguanine) by DNA polymerase $\mathrm{\kappa}$ in human cells. Chem. Res. Toxicol. 2012, 25, 1771-1776. [CrossRef] [PubMed]

228. Makarova, A.V.; Kulbachinskiy, A.V. Structure of human DNA polymerase iota and the mechanism of DNA synthesis. Biochemistry (Mosc.) 2012, 77, 547-561. [CrossRef] [PubMed]

229. Sharma, S.; Helchowski, C.M.; Canman, C.E. The roles of DNA polymerase $\zeta$ and the Y family DNA polymerases in promoting or preventing genome instability. Mutat. Res. 2013, 743-744, 97-110. [CrossRef]

230. Yang, W. An overview of Y-Family DNA polymerases and a case study of human DNA polymerase $\eta$. Biochemistry 2014, 53, 2793-2803. [CrossRef] [PubMed]

231. Makarova, A.V.; Burgers, P.M. Eukaryotic DNA polymerase $\zeta$. DNA Repair 2015, 29, 47-55. [CrossRef]

232. Johnson, R.E.; Washington, M.T.; Haracska, L.; Prakash, S.; Prakash, L. Eukaryotic polymerases ı and $\zeta$ act sequentially to bypass DNA lesions. Nature 2000, 406, 1015-1019. [CrossRef] [PubMed] 
233. Livneh, Z.; Ziv, O.; Shachar, S. Multiple two-polymerase mechanisms in mammalian translesion DNA synthesis. Cell Cycle 2010, 9, 729-735. [CrossRef] [PubMed]

234. Tissier, A.; McDonald, J.P.; Frank, E.G.; Woodgate, R. polı, a remarkably error-prone human DNA polymerase. Genes Dev. 2000, 14, 1642-1650. [PubMed]

235. Zhang, Y.; Yuan, F.; Wu, X.; Wang, Z. Preferential incorporation of G opposite template T by the low-fidelity human DNA polymerase ı. Mol. Cell. Biol. 2000, 20, 7099-7108. [CrossRef] [PubMed]

236. Bebenek, K.; Tissier, A.; Frank, E.G.; McDonald, J.P.; Prasad, R.; Wilson, S.H.; Woodgate, R.; Kunkel, T.A. 5'-Deoxyribose phosphate lyase activity of human DNA polymerase ı in vitro. Science 2001, 291, 2156-2159. [CrossRef]

237. Miropolskaya, N.; Petushkov, I.; Kulbachinskiy, A.; Makarova, A.V. Identification of amino acid residues involved in the dRP-lyase activity of human Pol ı. Sci. Rep. 2017, 7, 10194. [CrossRef] [PubMed]

238. Nair, D.T.; Johnson, R.E.; Prakash, S.; Prakash, L.; Aggarwal, A.K. Replication by human DNA polymerase-ı occurs by Hoogsteen base-pairing. Nature 2004, 430, 377-380. [CrossRef]

239. Nair, D.T.; Johnson, R.E.; Prakash, L.; Prakash, S.; Aggarwal, A.K. Human DNA polymerase ı incorporates dCTP opposite template G via a G.C+ Hoogsteen base pair. Structure 2005, 13, 1569-1577. [CrossRef]

240. Nair, D.T.; Johnson, R.E.; Prakash, L.; Prakash, S.; Aggarwal, A.K. Hoogsteen base pair formation promotes synthesis opposite the $1, N^{6}$-ethenodeoxyadenosine lesion by human DNA polymerase ı. Nat. Struct. Mol. Biol. 2006, 13, 619-625. [CrossRef]

241. Johnson, R.E.; Prakash, L.; Prakash, S. Biochemical evidence for the requirement of Hoogsteen base pairing for replication by human DNA polymerase ı. Proc. Natl Acad. Sci. USA 2005, 102, 10466-10471. [CrossRef] [PubMed]

242. Makarova, A.V.; Ignatov, A.; Miropolskaya, N.; Kulbachinskiy, A. Roles of the active site residues and metal cofactors in noncanonical base-pairing during catalysis by human DNA polymerase iota. DNA Repair 2014, 22, 67-76. [CrossRef] [PubMed]

243. Johnson, R.E.; Prakash, S.; Prakash, L. Efficient bypass of a thymine-thymine dimer by yeast DNA polymerase, Poln. Science 1999, 283, 1001-1004. [CrossRef]

244. Masutani, C.; Kusumoto, R.; Yamada, A.; Dohmae, N.; Yokoi, M.; Yuasa, M.; Araki, M.; Iwai, S.; Takio, K.; Hanaoka, F. The XPV (xeroderma pigmentosum variant) gene encodes human DNA polymerase $\eta$. Nature 1999, 399, 700-704. [CrossRef] [PubMed]

245. Kusumoto, R.; Masutani, C.; Iwai, S.; Hanaoka, F. Translesion synthesis by human DNA polymerase $\eta$ across thymine glycol lesions. Biochemistry 2002, 41, 6090-6099. [CrossRef] [PubMed]

246. Zhao, Y.; Biertümpfel, C.; Gregory, M.T.; Hua, Y.-J.; Hanaoka, F.; Yang, W. Structural basis of human DNA polymerase $\eta$-mediated chemoresistance to cisplatin. Proc. Natl Acad. Sci. USA 2012, 109, 7269-7274. [CrossRef] [PubMed]

247. Patra, A.; Zhang, Q.; Lei, L.; Su, Y.; Egli, M.; Guengerich, F.P. Structural and kinetic analysis of nucleoside triphosphate incorporation opposite an abasic site by human translesion DNA polymerase $\eta$. J. Biol. Chem. 2015, 290, 8028-8038. [CrossRef] [PubMed]

248. Patra, A.; Zhang, Q.; Guengerich, F.P.; Egli, M. Mechanisms of insertion of dCTP and dTTP opposite the DNA lesion $O^{6}$-methyl-2'-deoxyguanosine by human DNA polymerase $\eta$. J. Biol. Chem. 2016, 291, 24304-24313. [CrossRef]

249. Boldinova, E.O.; Ignatov, A.; Kulbachinskiy, A.; Makarova, A.V. The active site residues Gln55 and Arg73 play a key role in DNA damage bypass by S. cerevisiae Pol $\eta$. Sci. Rep. 2018, 8, 10314. [CrossRef] [PubMed]

250. de Padula, M.; Slezak, G.; Auffret van Der Kemp, P.; Boiteux, S. The post-replication repair RAD18 and RAD6 genes are involved in the prevention of spontaneous mutations caused by 7,8-dihydro-8-oxoguanine in Saccharomyces cerevisiae. Nucleic Acids Res. 2004, 32, 5003-5010. [CrossRef]

251. Mudrak, S.V.; Welz-Voegele, C.; Jinks-Robertson, S. The polymerase $\eta$ translesion synthesis DNA polymerase acts independently of the mismatch repair system to limit mutagenesis caused by 7,8-dihydro-8-oxoguanine in yeast. Mol. Cell. Biol. 2009, 29, 5316-5326. [CrossRef] [PubMed]

252. Carlson, K.D.; Washington, M.T. Mechanism of efficient and accurate nucleotide incorporation opposite 7,8-dihydro-8-oxoguanine by Saccharomyces cerevisiae DNA polymerase $\eta$. Mol. Cell. Biol. 2005, 25, 2169-2176. [CrossRef] [PubMed] 
253. Yung, C.; Suzuki, T.; Okugawa, Y.; Kawakami, A.; Loakes, D.; Negishi, K.; Negishi, T. Nucleotide incorporation against 7,8-dihydro-8-oxoguanine is influenced by neighboring base sequences in TLS DNA polymerase reaction. Nucleic Acids Symp. Ser. 2007, 51,49-50. [CrossRef] [PubMed]

254. Yasui, M.; Dong, H.; Bonala, R.R.; Suzuki, N.; Ohmori, H.; Hanaoka, F.; Johnson, F.; Grollman, A.P.; Shibutani, S. Mutagenic properties of 3-(deoxyguanosin- $N^{2}$-yl)-2-acetylaminofluorene, a persistent acetylaminofluorene-derived DNA adduct in mammalian cells. Biochemistry 2004, 43, 15005-15013. [CrossRef]

255. Minko, I.G.; Harbut, M.B.; Kozekov, I.D.; Kozekova, A.; Jakobs, P.M.; Olson, S.B.; Moses, R.E.; Harris, T.M.; Rizzo, C.J.; Lloyd, R.S. Role for DNA polymerase $\kappa$ in the processing of $N^{2}-N^{2}$-guanine interstrand cross-links. J. Biol. Chem. 2008, 283, 17075-17082. [CrossRef]

256. Jha, V.; Bian, C.; Xing, G.; Ling, H. Structure and mechanism of error-free replication past the major benzo[a]pyrene adduct by human DNA polymerase k. Nucleic Acids Res. 2016, 44, 4957-4967. [CrossRef] [PubMed]

257. Zhao, L.; Pence, M.G.; Christov, P.P.; Wawrzak, Z.; Choi, J.-Y.; Rizzo, C.J.; Egli, M.; Guengerich, F.P. Basis of miscoding of the DNA adduct $N^{2}, 3$-ethenoguanine by human Y-family DNA polymerases. J. Biol. Chem. 2012, 287, 35516-35526. [CrossRef] [PubMed]

258. Chang, S.-C.; Fedeles, B.I.; Wu, J.; Delaney, J.C.; Li, D.; Zhao, L.; Christov, P.P.; Yau, E.; Singh, V.; Jost, M.; et al. Next-generation sequencing reveals the biological significance of the $N^{2}, 3$-ethenoguanine lesion in vivo. Nucleic Acids Res. 2015, 43, 5489-5500. [CrossRef] [PubMed]

259. Fischhaber, P.L.; Gerlach, V.L.; Feaver, W.J.; Hatahet, Z.; Wallace, S.S.; Friedberg, E.C. Human DNA polymerase $\kappa$ bypasses and extends beyond thymine glycols during translesion synthesis in vitro, preferentially incorporating correct nucleotides. J. Biol. Chem. 2002, 277, 37604-37611. [CrossRef]

260. Vasquez-Del Carpio, R.; Silverstein, T.D.; Lone, S.; Swan, M.K.; Choudhury, J.R.; Johnson, R.E.; Prakash, S.; Prakash, L.; Aggarwal, A.K. Structure of human DNA polymerase $\mathrm{k}$ inserting dATP opposite an 8-oxoG DNA lesion. PLoS ONE 2009, 4, e5766. [CrossRef]

261. Patro, J.N.; Urban, M.; Kuchta, R.D. Interaction of human DNA polymerase $\alpha$ and DNA polymerase I from Bacillus stearothermophilus with hypoxanthine and 8-oxoguanine nucleotides. Biochemistry 2009, 48, 8271-8278. [CrossRef]

262. Batra, V.K.; Beard, W.A.; Hou, E.W.; Pedersen, L.C.; Prasad, R.; Wilson, S.H. Mutagenic conformation of 8-oxo-7,8-dihydro-2'-dGTP in the confines of a DNA polymerase active site. Nat. Struct. Mol. Biol. 2010, 17, 889-890. [CrossRef]

263. Burak, M.J.; Guja, K.E.; Garcia-Diaz, M. Nucleotide binding interactions modulate dNTP selectivity and facilitate 8-oxo-dGTP incorporation by DNA polymerase lambda. Nucleic Acids Res. 2015, 43, 8089-8099. [CrossRef] [PubMed]

264. Freudenthal, B.D.; Beard, W.A.; Perera, L.; Shock, D.D.; Kim, T.; Schlick, T.; Wilson, S.H. Uncovering the polymerase-induced cytotoxicity of an oxidized nucleotide. Nature 2015, 517, 635-639. [CrossRef] [PubMed]

265. Whitaker, A.M.; Smith, M.R.; Schaich, M.A.; Freudenthal, B.D. Capturing a mammalian DNA polymerase extending from an oxidized nucleotide. Nucleic Acids Res. 2017, 45, 6934-6944. [CrossRef] [PubMed]

266. Katafuchi, A.; Sassa, A.; Niimi, N.; Grúz, P.; Fujimoto, H.; Masutani, C.; Hanaoka, F.; Ohta, T.; Nohmi, T. Critical amino acids in human DNA polymerases $\eta$ and $\kappa$ involved in erroneous incorporation of oxidized nucleotides. Nucleic Acids Res. 2010, 38, 859-867. [CrossRef]

267. Shimizu, M.; Gruz, P.; Kamiya, H.; Kim, S.-R.; Pisani, F.M.; Masutani, C.; Kanke, Y.; Harashima, H.; Hanaoka, F.; Nohmi, T. Erroneous incorporation of oxidized DNA precursors by Y-family DNA polymerases. EMBO Rep. 2003, 4, 269-273. [CrossRef]

268. Shimizu, M.; Gruz, P.; Kamiya, H.; Masutani, C.; Xu, Y.; Usui, Y.; Sugiyama, H.; Harashima, H.; Hanaoka, F.; Nohmi, T. Efficient and erroneous incorporation of oxidized DNA precursors by human DNA polymerase $\eta$. Biochemistry 2007, 46, 5515-5522. [CrossRef] [PubMed]

269. Satou, K.; Hori, M.; Kawai, K.; Kasai, H.; Harashima, H.; Kamiya, H. Involvement of specialized DNA polymerases in mutagenesis by 8-hydroxy-dGTP in human cells. DNA Repair 2009, 8, 637-642. [CrossRef] [PubMed]

(C) 2019 by the authors. Licensee MDPI, Basel, Switzerland. This article is an open access article distributed under the terms and conditions of the Creative Commons Attribution (CC BY) license (http://creativecommons.org/licenses/by/4.0/). 